\title{
Structure and evolution of the "Olistostrome" complex of the Gibraltar Arc in the Gulf of Cádiz (eastern Central Atlantic): evidence from two long seismic cross-sections
}

\author{
T. Medialdea ${ }^{\mathrm{a}, *}$, R. Vegas ${ }^{\mathrm{b}}$, L. Somoza ${ }^{\mathrm{a}}$, J.T. Vázquez $^{\mathrm{c}}$, A. Maldonado ${ }^{\mathrm{d}}$, \\ V. Díaz-del-Río ${ }^{\mathrm{e}}$, A. Maestro ${ }^{\mathrm{a}}$, D. Córdoba ${ }^{\mathrm{f}}$, M.C. Fernández-Puga ${ }^{\mathrm{c}}$ \\ ${ }^{a}$ Marine Geology Division, Instituto Geológico y Minero de España, IGME, Ríos Rosas 23, Madrid 28003, Spain \\ ${ }^{\mathrm{b}}$ Depto. de Geodinámica, Fac. C. Geológicas, Universidad Complutense, Madrid 28040, Spain \\ ${ }^{\mathrm{c}}$ Facultad de Ciencias del Mar, Universidad de Cádiz, Puerto Real, Cádiz 1510, Spain \\ 'Instituto Andaluz de Ciencias de la Tierra, CSIC/Universidad de Granada, Granada 18002, Spain

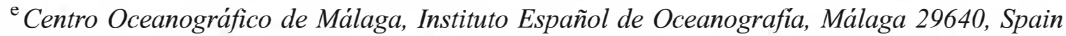 \\ ${ }^{\mathrm{f}}$ Depto. de Geofisica, Fac. C. Físicas, Universidad Complutense, Madrid 28040, Spain
}

\begin{abstract}
Reflection profiles characterize the structure and the upper Mesozoic to Cenozoic deposits of the Gulf of Cádiz region. Two long ENE-WSW multichannel seismic lines (ca. $400-500 \mathrm{~km} \mathrm{long}$ ) are analyzed to study the evolution of the area from the continental shelf to the Horseshoe and Seine abyssal plains. The huge allochthonous deposits emplaced in this region (the socalled "Olistostrome" of the Gulf of Cadiz) are described in terms of three different domains on the basis of the seismic architecture, the main tectonic features and the nature of the basement, oceanic or continental. The eastern domain extends along the continental shelf and upper and middle slope and corresponds to the offshore extension of the Betic-Rifean external front. It is characterized by salt and shale nappes later affected by extensional collapses. The central domain develops along the lower slope between the Betic-Rifean front and the abyssal plains and is characterized by a change in dip of the allochthonous basal surface and the basement. The allochthonous masses were emplaced by a combined gravitational and tectonic mechanism. The northern boundary of this domain is marked by the occurrence of an outstanding WNW-ESE-trending thrust fault with a strike-slip component, termed here as the Gorringe-Horseshoe fault. The westernmost domain corresponds to the abyssal plains, where the distal emplacement of the allochthonous body takes place; it is characterized by thrust faults affecting both the sedimentary cover and the oceanic basement. The allochthonous masses show a less chaotic character and the thickness decreases notably. These domains represent different evolutionary steps in the mechanisms of emplacement of the allochthonous units. The eastern domain of the allochthonous units was emplaced as part of the pre-Messinian orogenic wedge related to the collision that gave rise to the Betic-Rifean Belt, whereas the allochthonous wedge of the central and western domains were emplaced later as a consequence of the NE-SW late Miocene compression that continues in present times.
\end{abstract}

Keywords: tectonics; olistostromes; Gulf of Cadiz; Southwest Iberia continental margin; seismic profiles 


\section{Introduction}

The Gulf of Cádiz region straddles the E-W trending segment of the Eurasian-African plate boundary that extends from Azores to the Mediterranean Sea, between the Gloria Fault and the western end of the Alpine Mediterranean belt: the Gibraltar Arc (Fig. 1). The diffuse nature of this segment of the plate boundary is widely accepted on the basis of the related seismicity, that is characterized by scattered shalløw-and intermediate-type earthquakes (Vázquez and Vegas, 2000). Earthquake fault plane sølutions (Grimisøn and Chen, 1986; Buforn et al., 1995; Jiménez-Munt and Negredo, 2003) support the existence of a wide transpression zone ascribed to the sløw (2-4 $\mathrm{mm} /$ year) $\bullet b l i q u e ~ N W-S E$ convergence that initiated in the late Miøcene (Dewey et al., 1989; Argus et al., 1989).

The Gulf •f Cádiz is als• a relevant area, as it comprises the ocean-continent boundaries of the African and Iberian margins, in spite that the exact

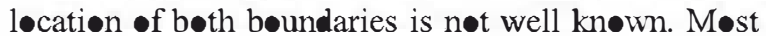
of the Gulf of Cádiz is floored by continental crust that thins to the west (Gónzalez-Fernández et al., 2001), whereas the oceanic crust is found at the Gorringe Bank, Horseshøe and Seine Abyssal Plains (Purdy, 1975; Røeser et al., 2002).

In the wake of the opening of the Central Atlantic, the geodynamic evolution of the Gulf of Cádiz has been ruled by $\mathrm{N}-\mathrm{S}$ Africa-Eurasia convergence. This plate convergence lasted from mid-Oligecene up to late Miocene times and then continued with slow late

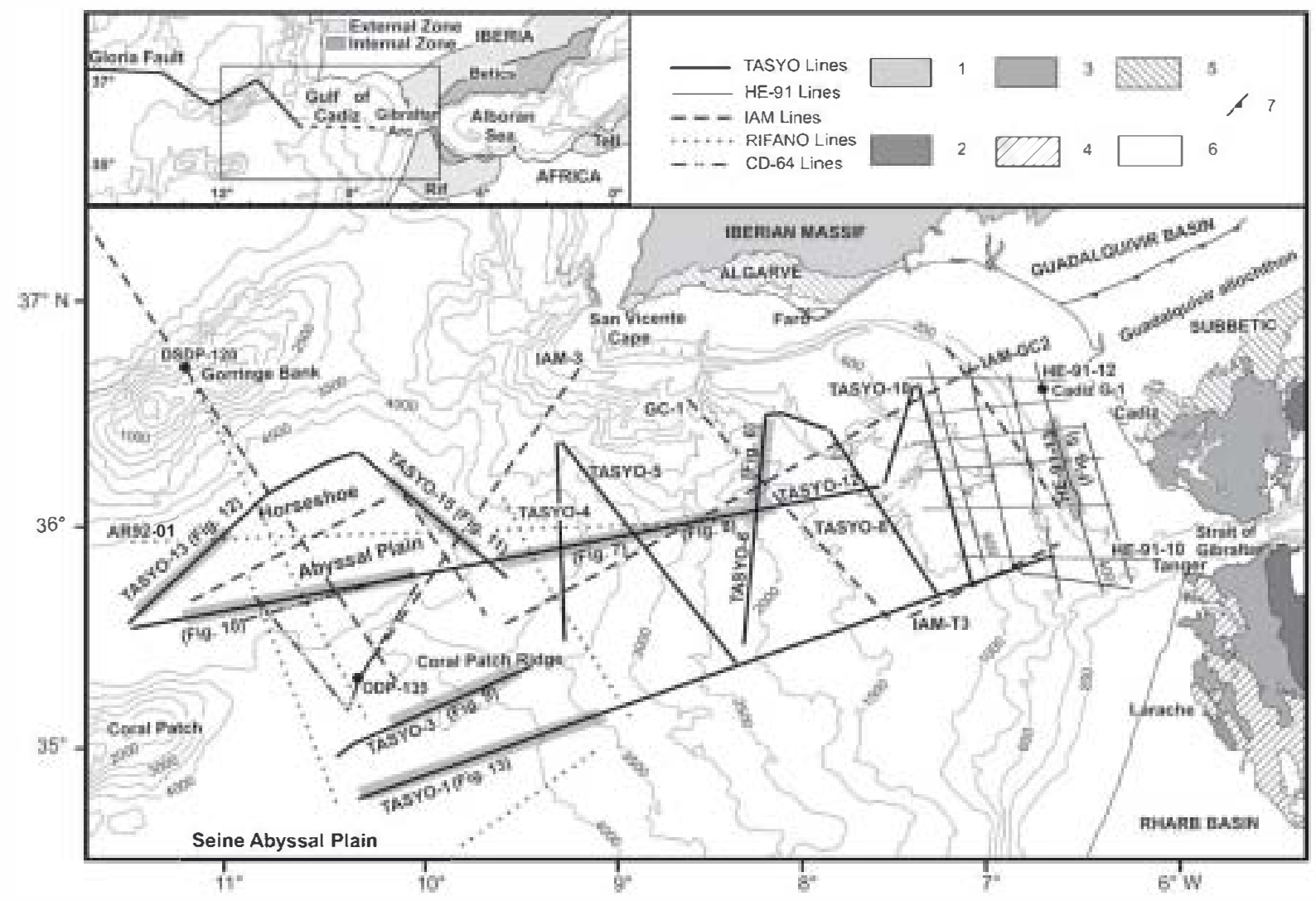

Fig. 1. Location map of Tasyo and HE-91 MCS lines and previous surveys in the Gulf of Cádiz: ARIFANO lines (Sartori et al., 1994; Torelli et al., 1997), IAM lines (Tortella et al., 1997; González-Femández et al., 2001), CD lines (Hayward et al., 1999). Shaded areas denote the rack of seismic lines displayed in the following figures. Inset shows plate tectonic setting with plate boundaries as solid lines. (1) South Portuguese Zone of the Iberian Massif, (2) Complexes of the Alborán Domain, (3) Flysch units, (4) Mesozoic Maghrebian Domain Cover, (5) Mesozoic South Iberian Domain Cover, (6) Neogene-Quaternary Deposits, (7) Guadalquivir Allochthon boundary onland. 
Miocene to recent NW convergence (Dewey et al., 1989; Srivastava et al., 1990; Røsenbaum et al., 2002). Westward drift and cøllision of the Alborán Domain with the north African and south Iberian margins in the early-middle Miecene, caused the development of the Rif and Betic orøen, and as a consequence the radial emplacement of huge alløchth-

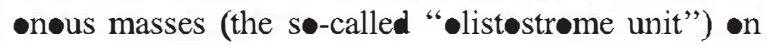
the Guadalquivir Basin (Iberian foreland), Rharb Basin (North African foreland) and Gulf of Cádiz (Perconig, 1960-1962; Flinch and Vail, 1998; Torelli et al., 1997; Maldonade et al., 1999; Gràcia et al., 2003a).

Since the chaotic body was recognized onland in the sixties (Perconig, 1960-1962) and offshore in the følløwing decades (R॰berts, 1970; Lajat et al., 1975; Bonnin et al., 1975; Baldy et al., 1977; Malod and Møugen॰t, 1979; Maldonad॰ et al., 1999), variøus interpretations have been made to explain the emplacement mechanism of this allochthonous unit (including gravitational processes, debris-flow mechanisms, diapirism and tectonic melange, amøng others). These interpretations gave rise to different nomenclatures: "Olistostrome", "Guadalquivir alløchthøn" and "Guadalquivir accretionary wedge". There is, however, a general agreement on the age of emplacement, which has been established as late Tortonian in the Guadalquivir (Perconig, 1960-1962) and Rharb foreland basins (Flinch and Vail, 1998). A similar discussion has been carried on for the offshore prøløngation of this unit in the Gulf of Cádiz (Torelli et al., 1997; Tortella et al., 1997; Maldonado et al., 1999; S॰møza et al., 1999; Gutscher et al., 2002).

The tectonic setting of the Gulf of Cádiz has been sø far ascribed to three scenariøs: (a) Maldonado et al. (1999) proposed subduction of the intermediate-type Iberian crust under the Alborán microplate in a western Albøán subductiøn zøne and subsequent deformation of the lower plate in the form of crustal slices (oceanic slices at the Gulf of Cádiz). (b) Gutscher et al. (2002) considered that in the Gulf of Cádiz, these alløchthønøus masses represent an active accretionary complex related to a narrow east-dipping slab of •ceanic lith osphere west of the Gibraltar Arc, under the Alborán Sea. (c) Sartori et al. (1994) suggested that in the distal margin and Atlantic basin plains there is no subduction-related deformation, but the stresses are released across a $200-\mathrm{km}$ area between the Seine Abyssal Plain and the Gorringe Bank, withøut a defined plate margin. Vázquez and Vegas (2000) alsø supported a diffuse contractive deformation of the lithosphere due to the African-Iberia convergence. This diffuse deformation occurs at the long-lived Africa-Iberia interface, a "n॰t fully fledged" plate bøundary (Vegas, 2001). B॰th tectonic regimes - subduction and distributed compression deformation - have been related in the same tectonic frame by Vázquez and Vegas (2000).

The objective of this work is to contribute to the knowledge of the main tectonic structures and the evølution of the Gulf of Cádiz within the AfricanIberian Tertiary convergence. We analyze tw॰ long transects (ca. 400-500 km long) from the Cádiz continental shelf and Strait of Gibraltar to the Horseshøe and Seine Abyssal Plains. These sections have been mainly drawn on the basis of twø-long reflection seismic prøfiles, acquired during the

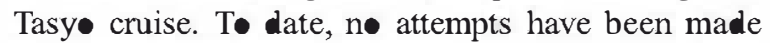
to explain the evolution of the olistostrome unit from the Guadalquivir Basin to the Atlantic abyssal plains. These cross-sections not only reveal the present tectonics and structure of the region, but alsø allow us to infer the gelogical evolution. The long sections are complemented, moreover, with additional Tasy॰ profiles that show detailed structures (Fig. 1).

\section{Geological background}

The main geological units that bound the Gulf of Cádiz are: the Algarve Basin in the north part, the South Portuguese Zøne of the Iberian Massif, that crops øut in søuthern Portugal, the Guadalquivir foreland basin to the east and the Betic-Rifean -røgenic belt, which extends from søuthern Iberia t॰ Morøcc through the Gibraltar Arc (Fig. 1).

The Algarve Basin extends along southern Portugal and the continental margin with an E-W direction. The basement is made up of Devonian and Carbøniferøus materials, which belong to the South Portuguese Zone, a Variscan SW verging fold-andthrust belt (Ribeir et al., 1983). The stratigraphic record of this basin extends from Late Triassic to Quaternary with a hiatus from Cenomanian to Mi cene. Nevertheless, Paleøene deposits have been 
found on the continental shelf, where borehøles have drilled sediments of Paleocene and Eøcene age. The evolution of the Algarve Basin within the south Iberian margin is characterized by the Alpine tectonic inversiøn $\bullet$ the Mesøzic extensiønal structures (Terrinha et al., 2002).

The Betic belt has been divided in terms $\bullet$ intemal and external zones. The former corresponds to the Alborán Domain Complexes and is made up of a stack of nappes mainly composed of Paleozøic to Triassic metamorphic rocks. The external zøne (Subbetic units) represent the søuth Iberian Mesøzic pale»margin, later incorperated int the belt and characterized by thin skinned tectonics. They consist of Triassic to lower Miocene deposits detached and thrusted towards the foreland. The Subbetic is overthrusted by the Flysch of Camp• de Gibraltar units, which contains Cretaceous to Miøcene siliciclastic depesits, mostly turbidites. These sediments were deposited in a deep trough located between the Iberian margin and

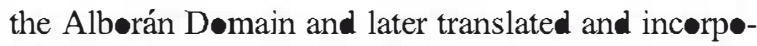
rated int the Gibraltar Arc belt (Azañón et al., 2002).

In the Cádiz area, twø sectors have been defined onland within the External Zøne (Berástegui et al., 1998; García-Castellanøs et al., 2002): a søuthwestern

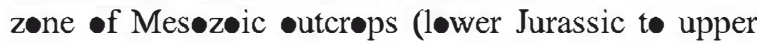
Cretaceous-Paleocene age), and to the north, a body which has been traditionally referred to as the Olistostrøme or Guadalquivir Alløchthøn, constituted by chaotic masses and a frontal Miocene north-verging imbricated wedge. This chaotic body consists of Triassic evaporites and red beds with blecks, mostly -f upper Cretaceøus to Pale gene limestones. It alsø invelves marlstones ranging from Aquitanian to Tortonian. The southeastern half of the Guadalquivir foreland basin is covere by this allochthonous unit, which near the coast reaches a width of $50 \mathrm{~km}$ and a thickness of 2-3 km (Flinch and Vail, 1998). These wedge-shaped alløchthøn us units extend from the Iberian Peninsula and Morecc (Prerifaine nappes at the Rharb foreland basin) to the Horseshøe and Seine Abyssal Plains.

\section{Methodology and data sources}

As part of the TASY Prøject, a multicharmel seismic reflection (MCS) survey was carried out in 2000 in the Gulf of Cádiz ab॰ard the B/O Hespérides. During this cruise, $1728 \mathrm{~km}$ of MCS seismic prøfiles were obtained crossing the area in ENE-WSW, NE$\mathrm{SW}$ and NW-SE directions (Fig. 1). Seismic data were acquire by means of a five BOLT airgun array -f 22.45 and 34.81 (line Tasy-3) of capacity and a TELEDYNE 96-charmel streamer of $2.5 \mathrm{~km}$ løng, and recorded for $10 \mathrm{~s}$ at a 2-ms sampling rate. The shot interval was $50 \mathrm{~m}$. Data processing (stacking and time migration) has been performed at the $\mathrm{B} / 0$ Hespérides and the Institute Andaluz de Ciencias de la Tierra (CSIC). The area was simultaneously surveyed with Simrad EM-12 multibeam ech• søunder.

Analysis of these new seismic data allow us to identify several seismic units and map the main tectonic features that have determined the general structure of the margin (Fig. 2). Additional MCS profiles •btained during HE-91 cruise as well as IAM seismic lines have als been analyzed to cœmplement the eastemmost part of the Gulf of Cádiz and the Horseshøe Abyssal Plain. The structures and seismic units identified on MCS lines have been tied to other profiles (Fig. 1) previously published by different authors in the area (Sartori et al., 1994; Torelli et al., 1997; Tortella et al., 1997; Hayward et al., 1999). Seismic unit ages have been assigned on the basis of tentative correlations with DSDP 135 and units defined by Maldonado et al. (1999).

Fig. 2. Swuctural map of the survey area based on interpretation of MCS lines. The map is supplemented in the Portuguese continental shelf with the Carta Geológica de Portugal a escala 1:500,000 (Serviços Geológicos de Portugal, 1992) and in the southwest Portuguese margin, the Marques de Pombal fault has been aced after Terrinha et al. (2003). Bathymetric contours from Tasyo multibeam data and Smith and Sandwell (1997). Crustal thickmess after Purdy (1975), Medialdea et al. (1986), González et al. (1998) and González-Femández et al. (2001). AH: Albufeira basement high; ALG: Algarve Basin; CB: Cádiz Basin; CPR: Coral Patch Ridge; DCC: Diego Cao Channel; F-A, F-A 1 , F-B, F-C, FC $_{1}$ : Fronts of the Allochthonous Units; FF: Flysch Front; GB: Guadalquivir Bank; GUALb: Guadalquivir Allochthon boundary (buried); GUALo: Guadalquivir Allochthon boundary (outcropping); HAP: Horseshoe Abyssal Plain; LC: Lagos Canyon; PC: Portimao Canyon; PH: Portimao basement high; SbF: Subbetic Front; SF: San Fernando; SVC: San Vicente Canyon. (1) South Portuguese Zone (Paleozoic), (2) Complexes of the Alborán Domain (Internal zone), (3) Flysch units, (4) Algarve Basin (Mesozoic), (5) Triassic deposits (External zone), (6) Mesozoic sediments (Extemal zone), (7) Neogene-Quatemary sediments. 


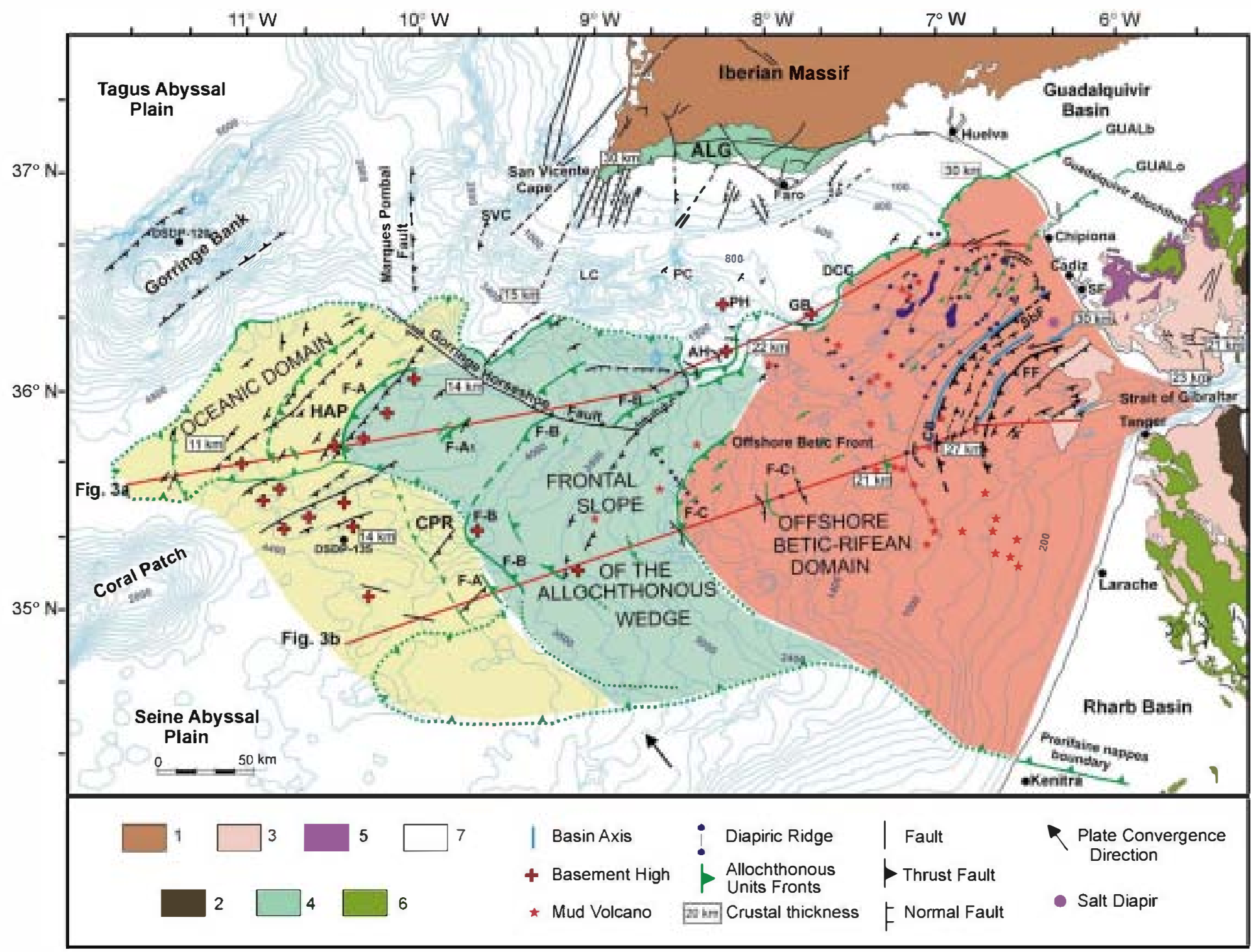


The current structure of the region and its evølution is envisaged through tw løn ENE-WSW linedrawings (Fig. 3). Beth line drawings are chiefly derived frøm the interpretation of MCS prøfiles Tasy॰-1 and Tasy $\bullet-12$. Nevertheless, in order to get

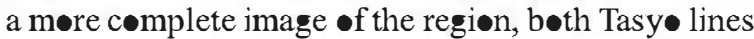
has been linked to MCS profiles IAM-T3 and HE-9110 and IAM-GC-2 and HE-91-12 lines, respectively (Tortella et al., 1997; González-Fernández et al., 2001). The structure of the lower crust and Mohe depth is base on velocity models, where depth has been converted to TWT (Gønzález-Fernández et al., 2001), and on other seismic data (Sartori et al., 1994). It should be considered, however, that these conversions might locally produce a distorted image of the crustal gemetry.

\section{Stratigraphic framework}

Five units are differentiated above the acoustic basement. These units range in thickness from: 2 $2.5 \mathrm{~s}$ (TWT) in the middle continental sløpe to $2-3.5 \mathrm{~s}$ (TWT) in the løwer sløpe, and again to 2-2.5 (TWT) in the basin plains (Fig. 3).

The complete stratigraphic sequence of the sedimentary cover in the Gulf •f Cádiz region is constituted by the following units (Fig. 4): (U1) a basal upper Jurassic-lower Aptian unit made up of marls and limestones, onlapping basement irregularities with a mean thickness of 400-600 ms TWT; (U2) an upper Cretaceous-løver Eøcene predominantly terrigenous unit (shales with chert layers and limestones at the base) deposited in a deep sea environment (Hayes et al., 1972) and with a fairly constant thickness of $400 \mathrm{~ms}$ TWT aløng the basin plains, that increases towards the slope (600-800 ms TWT); (U3) a unit that has been tentatively attributed the Upper Oligecene-Miøcene according to the stratigraphic position, that was only recognized on the Horseshøe Abyssal Plain and locally at the lower slope with a thickness of about $400 \mathrm{~ms}$ (TWT); (U4) the Alløchth-

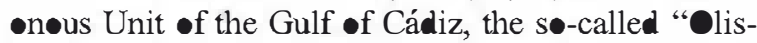
trostrome", (U5) a Miøcene-Quaternary Unit. This later unit is composed on the continental shelf and slope of Miocene marly clays and sands, and Plicene-Quaternary hemipelagic deposits, contourites and turbidite beds (Maldonado et al., 1999). On the søuthern edge of the Horseshøe Abyssal Plain, DSDP

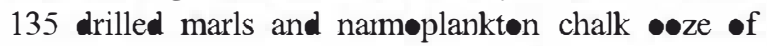
late Oligecene-early Miøcene to Pleistocene age (Hayes et al., 1972).

Due to its specific characteristics (unusual thickness and wide distribution) and the widely discussed mechanism of emplacement, the "-listostrome unit" merits independent attention. In this contribution, these deposits will be called the Allochthonous Unit of the Gulf of Cádiz (AUGC). This denomination avøids genetic implications, since more than one mechanism can be invoked along the evolution of the margin, as it will be farther discussed.

The wedge-shaped AUGC is constituted by a set $\bullet$ superposed sheets. Its thickness ranges from $0 \mathrm{~s}$ in the external front to $2.5 \mathrm{~s} \mathrm{TWT} \mathrm{(ab \bullet ut} 2.75 \mathrm{~km}$ assuming a veløcity •f $2.2 \mathrm{~km} / \mathrm{s}$, after Gønzález-Fernández et al., 2001). These masses have been seismically characterized by chatic reflectors and numerous diffractions and hyperbølic reflections. Nevertheless, towards the western external front as the thickness decreases, it is seismically more coherent and less deformed. The alløchthon drilled onshore in front of Chipiona (Cádiz G-1 in Fig. 1) where it is made up of marls and anhydrite (Maestr• et al., 2003).

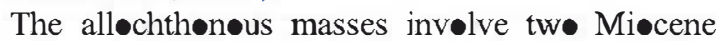
units defined in the continental shelf and upper slope by Maldonado et al. (1999): pre-ølistostrome unit M1 (Langhian-Serravallian and lower Tortonian) and syn-listostrøme unit M2 (upper Tørtonian). Fragments of Mesøz•ic and plastic Triassic materials and even lower Cenozøic units are als comprised in the AUGC, taking inte account seismic and well data (Maestro et al., 2003). On the continental shelf and upper slope the AUGC overthrusts unit M1, composed of grey and green clays, which is responsible of the marly diapirism in the Gulf of Cádiz. Similar data has been reported by Flinch and Vail (1998) in the southern margin of the Guadalquivir foreland basin.

\section{Structure of the Gulf of Cádiz from seismic interpretation}

The tectonics, seismic architecture, morphostructure and crustal structure of the area will be described and interpreted in terms of three key regions (Figs. 2 


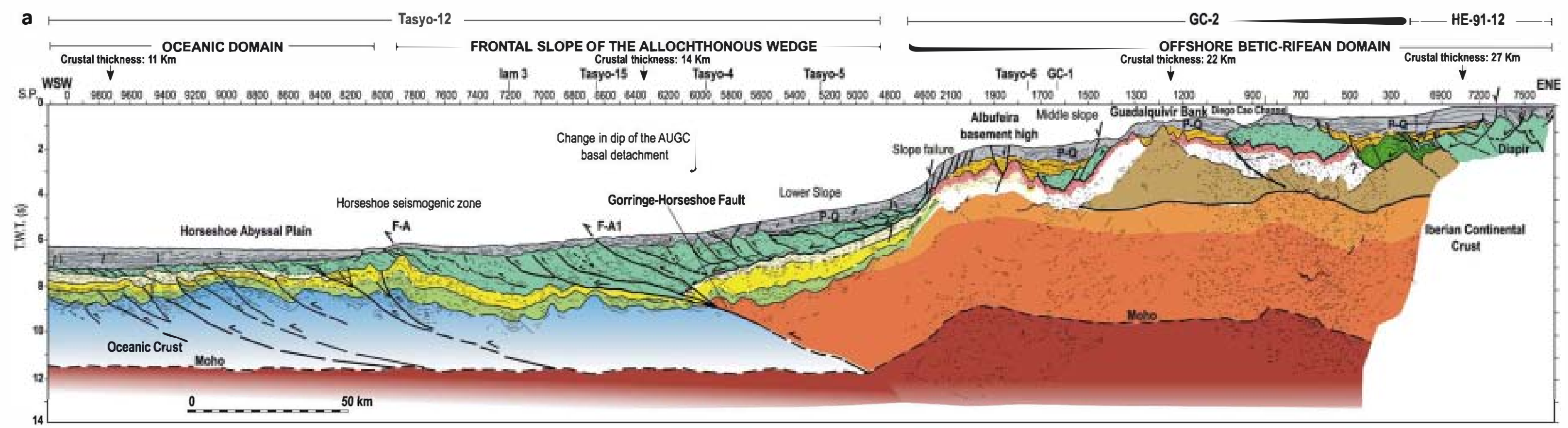

b
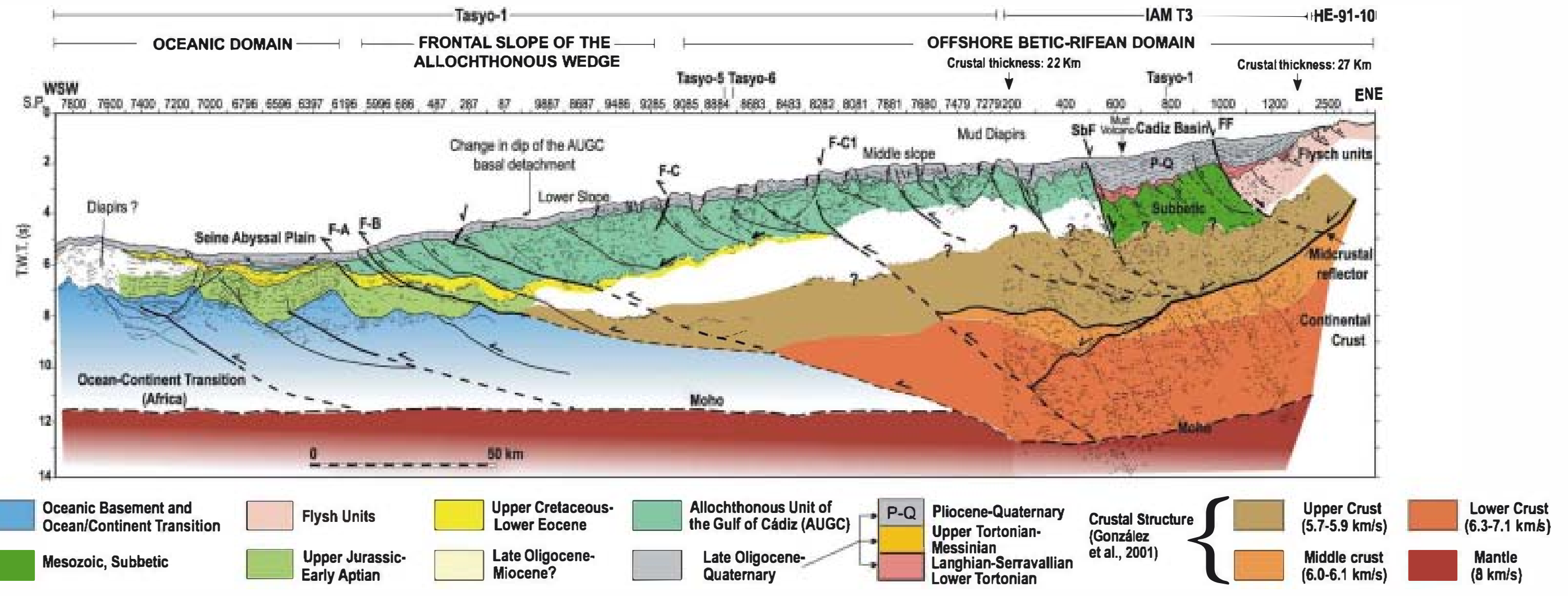

Fig. 3. Two cross-sections along the Gulf of Cádiz composed of line-drawings of MCS profles Tasyo 12, IAM GC-2 and HE-91-10 (a) and Tasyo 1, IAM-T3 and HE-91-12 (b). Crustal structure from depth to TWT time converted after González-Femández et al. (200 1) is superposed on both sections. Discussion in the text. See Fig. 2 for location. 
Gibraltar and overthrust the Subbetic units (Figs. 3a and 5). The Subbetic units include upper evaporitic Triassic units, affected by diapirism, and Mesøzoic to Tertiary carbønate and terrigenous deposits (Jurassic to late Oligøcene), which overlie the Paleozøic basement. Several diapirs have been identified offshore in this area, as for example a huge diapir close to the FlyschSubbetic boundary, seaward off San Fernand॰ (SF in Fig. 2), where a salt diapir outcrøps. Over the Subbetic and Flysch units, an arcuate basin (Cádiz Basin, CB in Fig. 2) with two marked depocenters løcated over the fronts of bøth units is remarkable in Fig. 3b (S.P. 600 and 1100), filled by a middle Miocene-Quaternary depositional sequence of more than $1 \mathrm{~s}$ TWT.

West of the Subbetic Front (SbF in Fig. 2), the AUGC develops as a set of superposed units that prøgrade seawards, reaching prøgressively further distances along a seaward dipping basal surface
(Fig. 3b). The chatic masses $\bullet$ the northern alløchthonous wedge front ๑verlie middle Miøcene depøsits, as for example close to the Portima basement high (Fig. 6).

The progressive westward migration of these units is responsible for the convex morph logy of the isøbaths on the sløpe, which appear as a fan-shaped bødy. The AUGC reaches the base of the middle slope at $2400 \mathrm{~m}$ water depth, and delineates the external boundary of this domain ( $\mathrm{F}-\mathrm{C}$ in Figs. 2 and $3 \mathrm{~b}$ ). In spite of the chaotic character attributed to the AUGC, the high quality of the seismic data allows us to distinguish the internal landward-dipping reflectors that represent the basal detachments of the successive imbricated bedies (Fig. 3b).

Extensional collapses and røll-øver structures are found at the back of the advancing alløchthon sheets (Maestr- et al., 2003). These features are
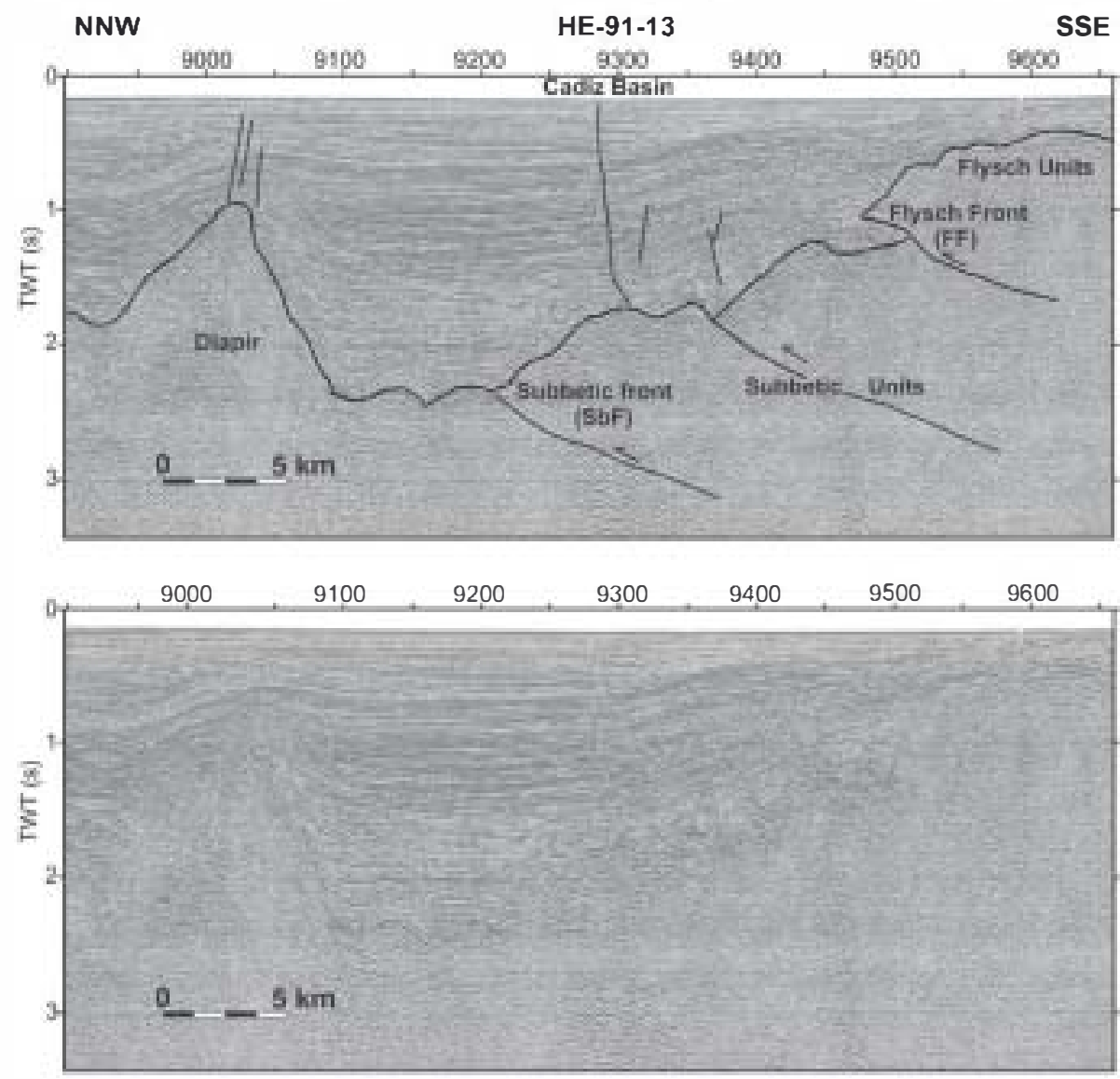

Fig. 5. Interpreted MCS line HE-91-13 and seismic profle across the Flysch and Subbetic units. Discussion in the text. See Fig. 1 for location. 


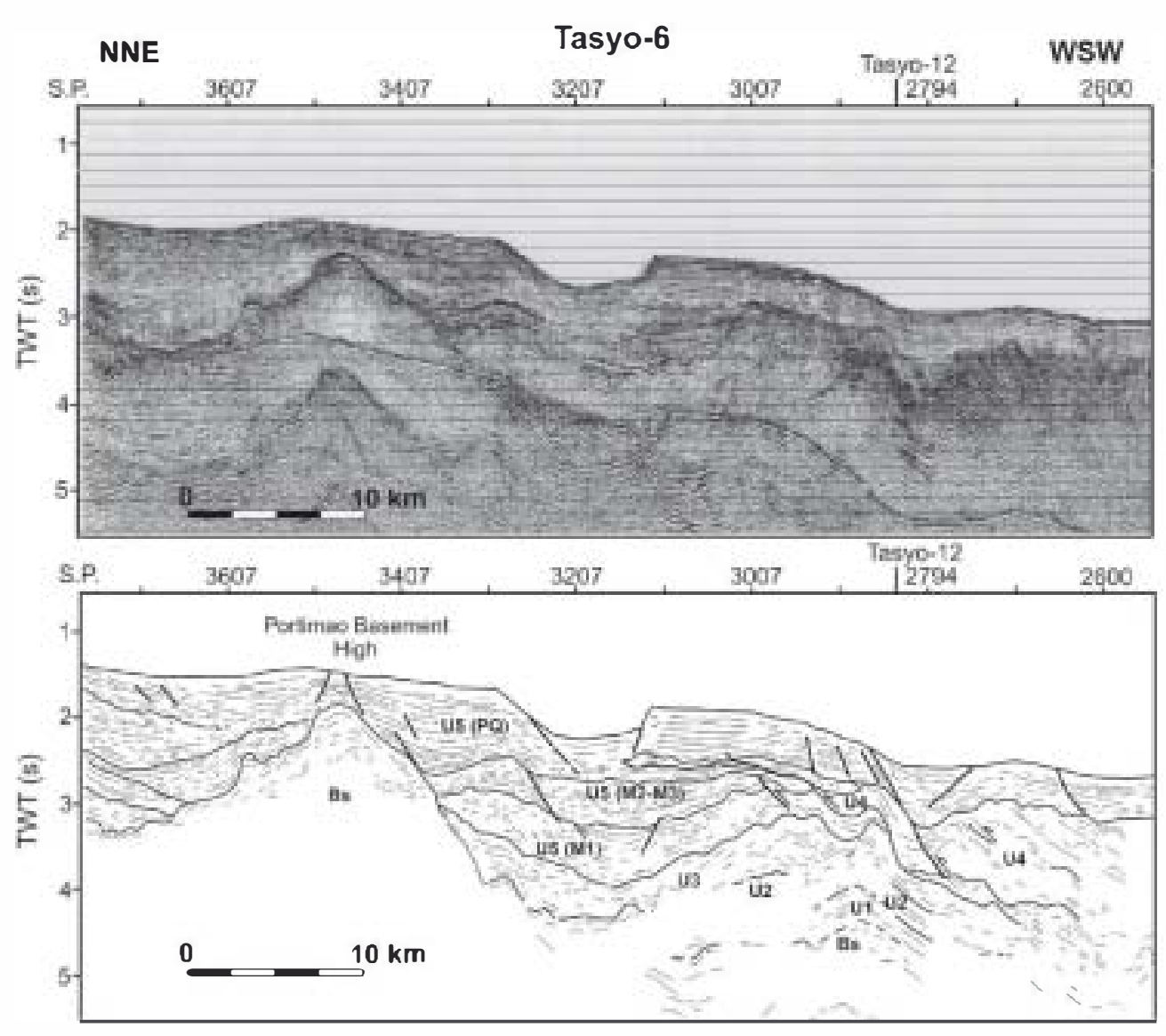

Fig. 6. Detail of the MCS line Tasyo-6 and line drawing in the Portimao basement high area, showing the external front of the AUGC. See Fig. 1 for location and Fig. 4 for seismic units explanation.

represented in Fig. 2, where several listric faults with an arcuate trace merge at the sea floor near the continental shelf break in front of Chipiona.

The irregular and undulating top of the alløchth॰nous unit frequently shows mounded geometries, that can either mark secondary fronts or gemetries related to diapirism (Figs. 3 and 5). Extensive mud diapirism and mud volcanism has been reported throughout the Gulf of Cádiz margin (S^møza et al., 2002; Pinheirø et al., 2003). On Fig. 2, the location of the main diapirs and mud volcanøes structures extending from the coast to the løwer sløpe are shøwn. In the northern Gulf of Cádiz, these diapirs display a NE-SW trend, parallel to the arcuate Subbetic Front and form a set of parallel ridges (Hernández-M•lina et al., 2003). Søuth of the Strait of Gibraltar, mud volcanøes followed a NNW-SSE trend.
Near the coast, the $30-\mathrm{km}$-thick continental crust thins progressively to $21-22 \mathrm{~km}$ approximately at $8^{\circ} \mathrm{W}$ (Gønzález-Fernández et al., 2001). Tw• basement highs that belong to the northern boundary of this domain are represented in Fig. 3a: the Guadalquivir Bank and the Albufeira basement high, located to the SW (Fig. 2), where the upper crust has been defined using wide-angle seismic reflection models. Taking int account that the Guadalquivir Bank is made up of Paleoz»ic røcks, it is prøposed that this uppermost layer represents the Søuth Portuguese Zøne. A prominent intracrustal reflector (Fig. 3b), asseciated with the top of the middle crust at $4 \mathrm{~s}$ TWT (approximately $5 \mathrm{~km}$ depth) beneath the Cádiz Basin, can be traced down to $10 \mathrm{~s}$ TWT (12 km depth) aløng an $80-\mathrm{km}$ long seaward dipping surface. This crustal boundary separates twø bløcks (upper and 
lower crust) with different reflection signatures. There are alsø grøups of upper crustal reflectors rising frøm this midcrustal region, which could be considered emerging thrusts ramping up int the upper crust from the midcrustal detachment zone.

\subsection{The fiontal slope of the allochthonous wedge: the transition to the basin plains}

The lower slope and rise is characterized by the -ccurrence of an outstanding WNW-ESE-trending fault, named here as the Gorringe-Horseshee fault, which lies søutheast of the Gorringe Bank and bounds the northeastern margin of the Horseshøe Abyssal Plain (Figs. 2 and 3a). An ther feature of this area is the change in inclination of the alløchthøn basal surface. The greatest thicknesses of the AUGC are reached in this domain, close to the Gorringe-Horseshøe fault (Fig. 3a).

The internal boundary of this region is well $\bullet b-$ served south of San Vicente Cape by an abrupt deepening $\bullet$ the basement $\bullet 2 \mathrm{~s}$ (TWT) from the Albufeira High aløng $15-20 \mathrm{~km}$, followed by a gentler deepening of $1.5 \mathrm{~s}$ (TWT) along $25 \mathrm{~km}$ (Figs. 3a and 7).

Three seismic units (U1, U2 and U3) of Late Jurassic to Miecene age underlie the AUGC (Fig. 3a). In contrast to the eastern domain, the AUGC (U4) seems to invelve the complete Miøcene depositional sequence and constitutes the bulk of the "infilling" of the slope basins. The abrupt deepening of the basement facilitates the gravitational collapse of the alløchthonous unit and the overlying sediments (Fig. 3a). As it can be observed in Fig. 7 (S.P. 4500-5500), several alløchthønous sheets have slid down due to

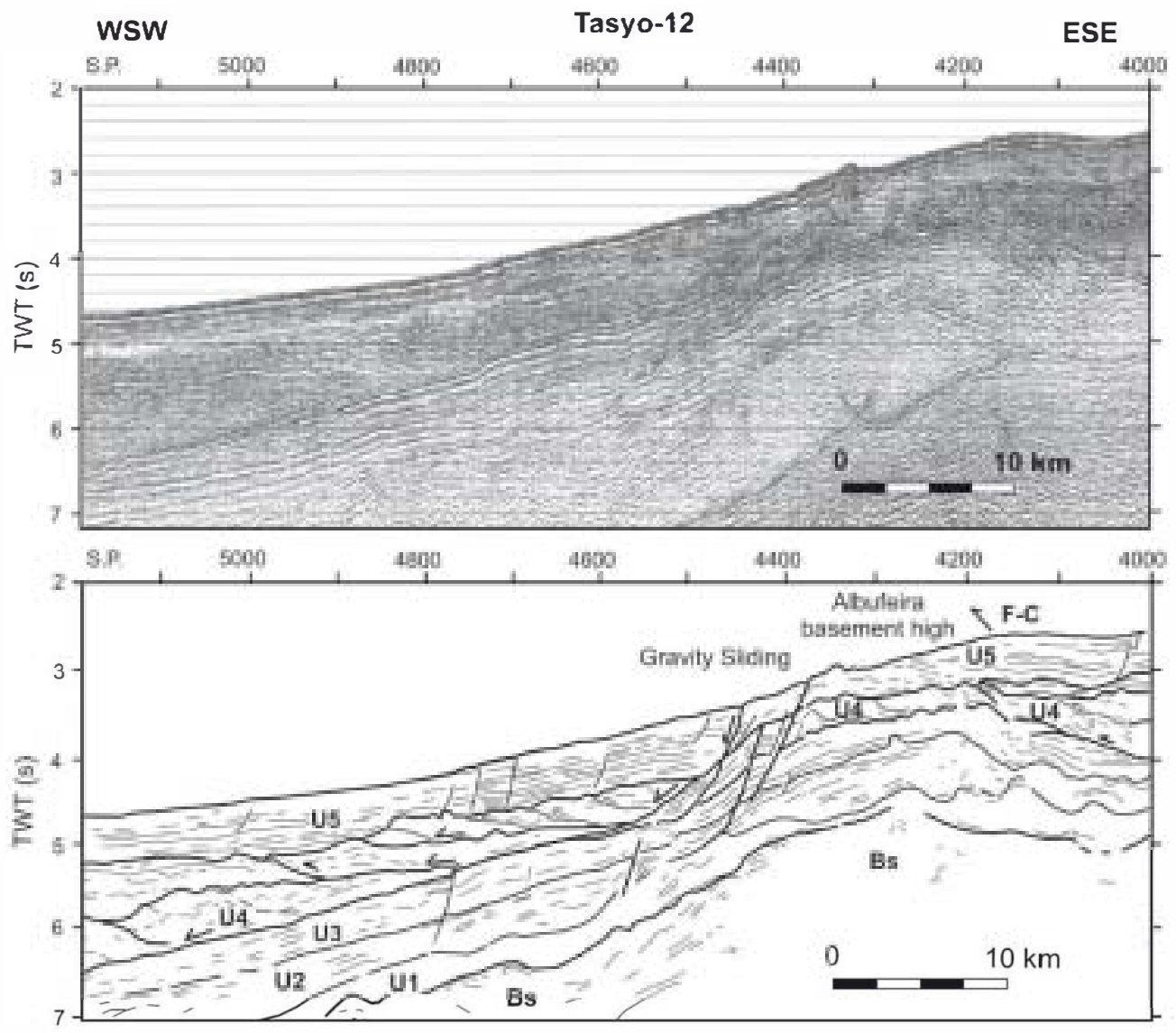

Fig. 7. Segment of MCS line Tasyo-12 and line drawing. Note the slope failure produce by gravity-driven advance of the allochthonous sheets at the base of the Albufeira High. See Fig. 1 for location and Fig. 4 for seismic units explanation. 
slope instability and appear superposed at the base of the Albufeira basement high. Extensional structures are produced at the slide head due to the gravitational forces that emplace the slope alløchthonøus masses. These gravitational faults determine the arcuate trace of the isøaths (Fig. 2).

The Gorringe-Horseshøe fault is an active thrust fault with a right-lateral strike-slip component that has been identified using seismic data and map criteria (Figs. 2, 3a and 8). It is $150 \mathrm{~km}$ long and has a NWSE direction that slightly changes at its eastern end. Neotectonic modelling of this part of the AfricaEurasia plate boundary carried •ut by Jiménez-Munt and Negrede (2003) has predicted NW-SE striking faults to have dextral motion and relatively high slip rates $\left(2.8 \mathrm{~mm}\right.$ year $\left.^{-1}\right)$. This fault, that has been

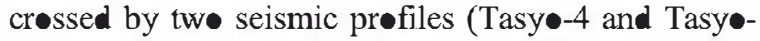
12), displaces the basement top and seemed to be rooted at the base of the crust, which lies at $12 \mathrm{~s}$ TWT at the løwer sløpe (Gønzález-Fernández et al., 2001).
It is interpreted to be located near the continent- -cean boundary, considering that crustal thickness reaches $14 \mathrm{~km}$ (Gønzález et al., 1996). We have als• reinterpreted this structure in the following seismic profiles (Fig. 1): ARFANO AR92-01 line, close to CDP 1400 (Torelli et al., 1997) and IAM-3 line, near CDP 4700 (González-Fernández et al., 2001; Tortella et al., 1997).

The Gorringe-Horseshøe fault offsets the unc»nformity between the basement and the sedimentary cover, but alsø cuts through the AUGC depesits to the seafleør. This fault produces tilting of the dep•sitional units (which appear northeastward dipping), due to the hangingwall load, lamination of the units and the outward advance of successive imbricates of the alløchthonøus wedges (Fig. 3a). The GorringeHorseshøe fault marks als a change of dip in the basal surface of the AUGC, that passes to verge from oceanward to landward, and induced a change in the mode of emplacement from gravitational to

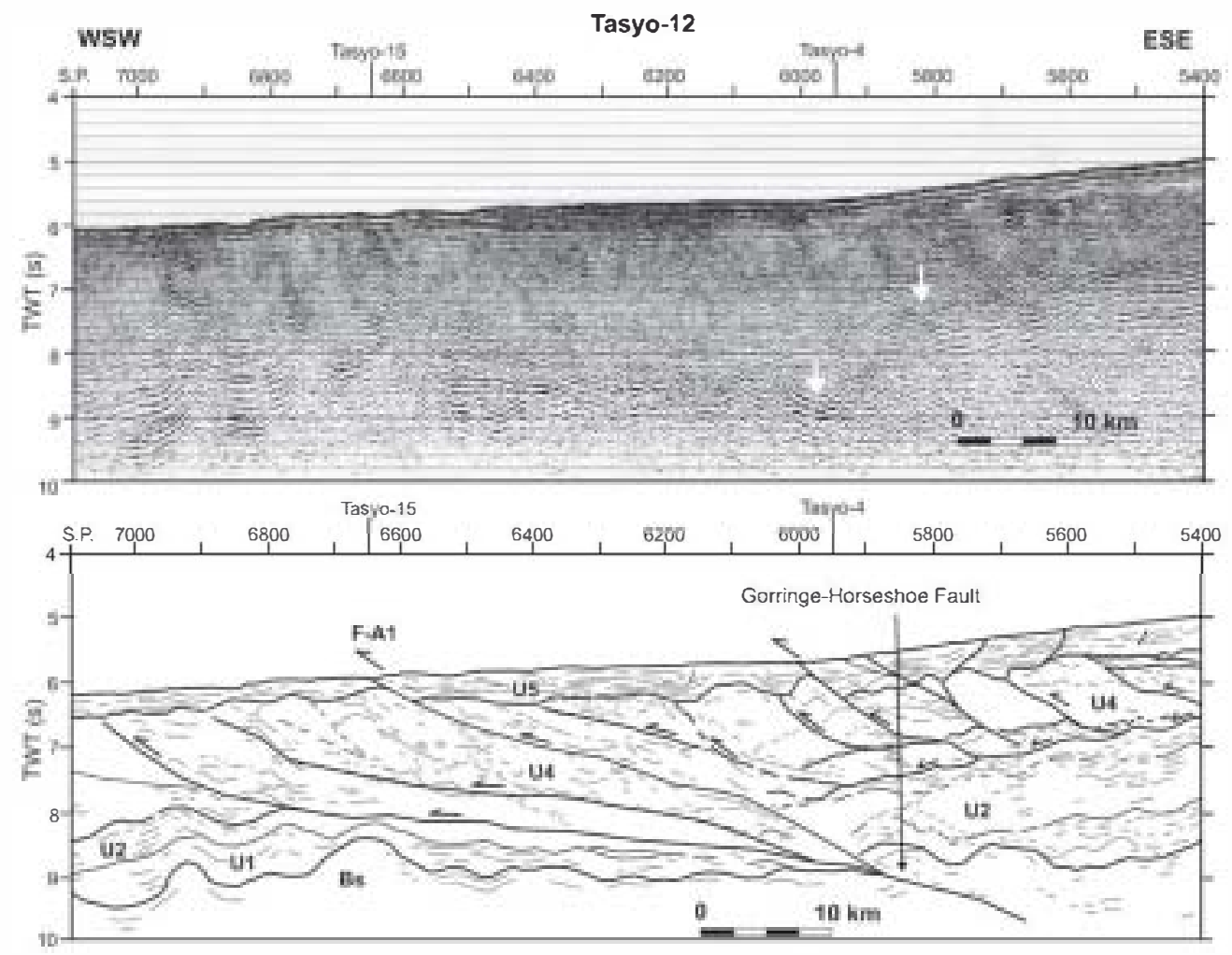

Fig. 8. Segment of MCS line Tasyo-12. Note the Gorringe-Horseshoe fault, which marks a change in the basement dip. Arrows denote the offset produced by the fault. See Fig. 1 for location and Fig. 4 for seismic units explanation. 


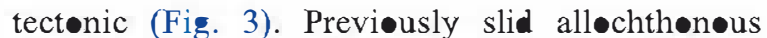
wedges of the slope were reactivated and transported seaward as illustrated by søme subfrønts: (between F-A $A_{1}$ and F-A in Figs. 2 and 3). The change of the basement dip is als $\bullet$ bserved in Fig. 3b, close to SP 80, where a fault of similar characteristics has been identified (F-C $\mathrm{C}_{1}$ in Figs. 2 and 3 ).
The Coral Patch Ridge constrained the seaward migration of the alløchthønous wedges and induced the divergence of the migration front, which

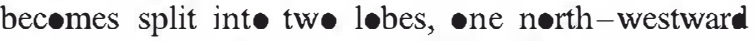
and another south-westward (Fig. 2). The external front $(\mathrm{F}-\mathrm{B})$ of the AUGC pinches out near the top -f the Coral Patch Ridge, where it is sealed by only
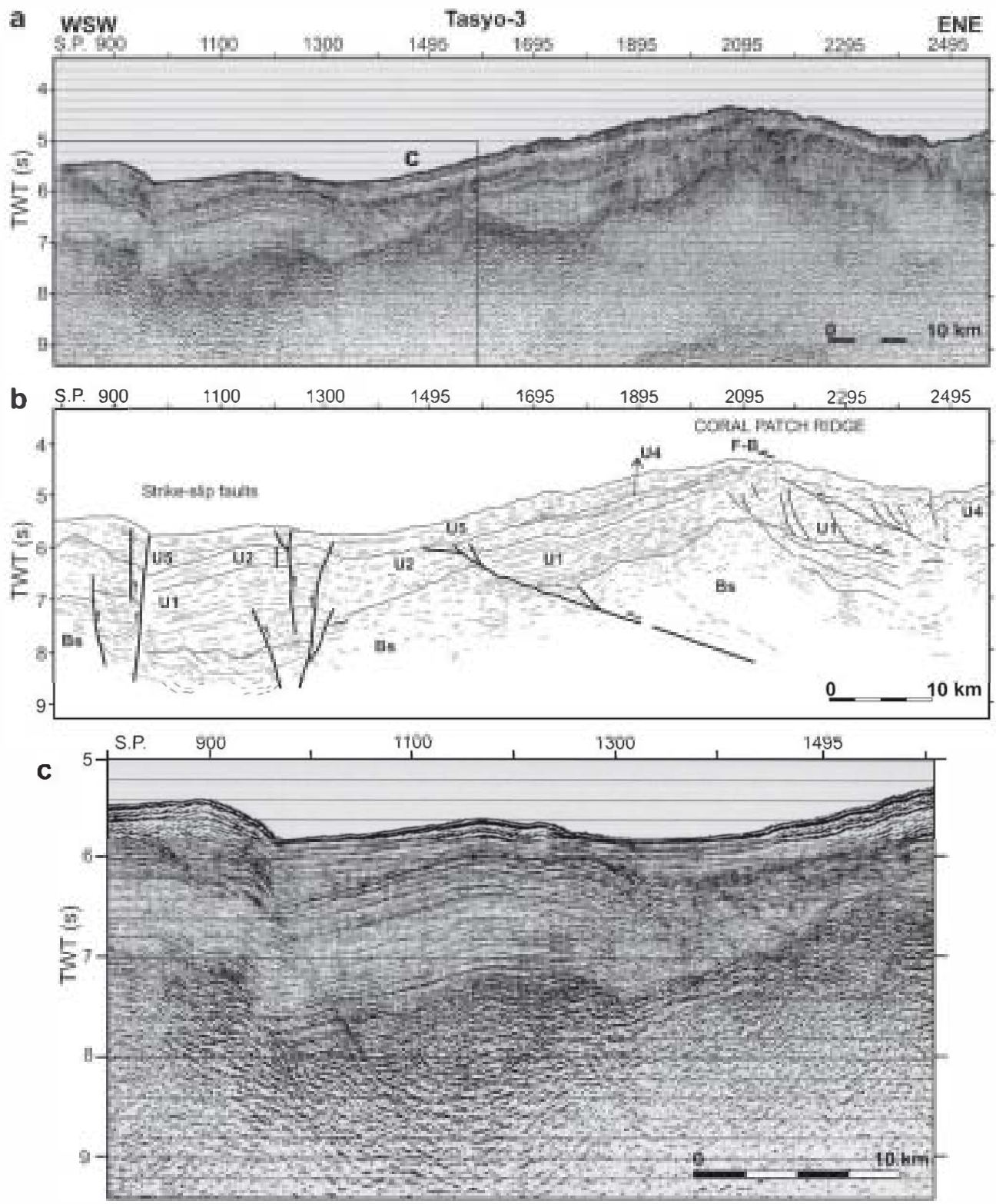

Fig. 9. MCS line Tasyo-3 (a) and line drawing (b) at the Coral Patch Ridge. Discussion in the text. Black box on the MCS line outlines a deniled section (c). See Fig. 1 for location and Fig. 4 for seismic units explanation. 
$200 \mathrm{~ms}$ TWT of Pliecene-Quaternary sediments (Fig. 9).

Gønzález et al. (1996) prøpøsed from the interpretation of the IAM-3 wide-angle seismic reflection prøfile (Fig. 1), a model for the crustal structure of this domain that shows a progressive thinning of the crust from abøut $30 \mathrm{~km}$ close to San Vicente Cape to $15 \mathrm{~km}(11 \mathrm{~km}$ below sea bott॰m) at 80-100 km from the coast. On the distal margin this thickness is maintained south-westward, close to the GorringeHorseshøe fault. In a NE-SW direction, crustal thickness changes from 22 to $14 \mathrm{~km}$ (Fig. 2).

5.3. The oceanic domain: the abyssal plains and the Coral Patch Ridge

This region is characterized by active thrust tectonics (Figs. 10 and 11). A slope of 600-700 m marks a change from the distal margin to the flat Horseshøe Abyssal Plain located at $4800 \mathrm{~m}$ depth (Fig. 10). The basin plain is bounded by tw॰ NE-SW majør reliefs: the Gorringe Bank and the Coral Patch Seamount
(Fig. 2). The Gorringe Bank is flanked by northwest and southeast-verging thrust faults (Ryan and Hsü, 1973; Mauffret et al., 1989; Le Gall et al., 1997; Galindo-Zaldívar et al., 2003). South of the Coral Patch Seamount, the Seine Abyssal Plain at 4300-4400 m depth is shalløwer than the Horseshøe Abyssal Plain.

\subsubsection{The Horseshoe Abyssal Plain}

The depøsitional sequence in the Hørseshøe Abyssal Plain is characterized by upper Jurassic to Miøcene sediments (U1, U2 and U3) •verlain by an alløchth$\bullet$ ๑ns wedge (U4) •f 400-500 ms (TWT) thick, that thins prøgressively until it disappears at abøut $11^{\circ} 5 \mathrm{~W}-12^{\circ} \mathrm{W}$. In the basin plain, a northwestward-verging thrust system trending NNE-SSW is -bserved (Figs. 2, 3a, 10 and 11). These thrust faults can be delineate by internal crustal reflectors that extend int the oceanic basement, fold the sedimentary cover and develop seafloor elevations (Figs. 10 and 11). In general, these thrust faults have a small horizontal component, and consequently the crustal shortening accommodate by each fault is minø. The
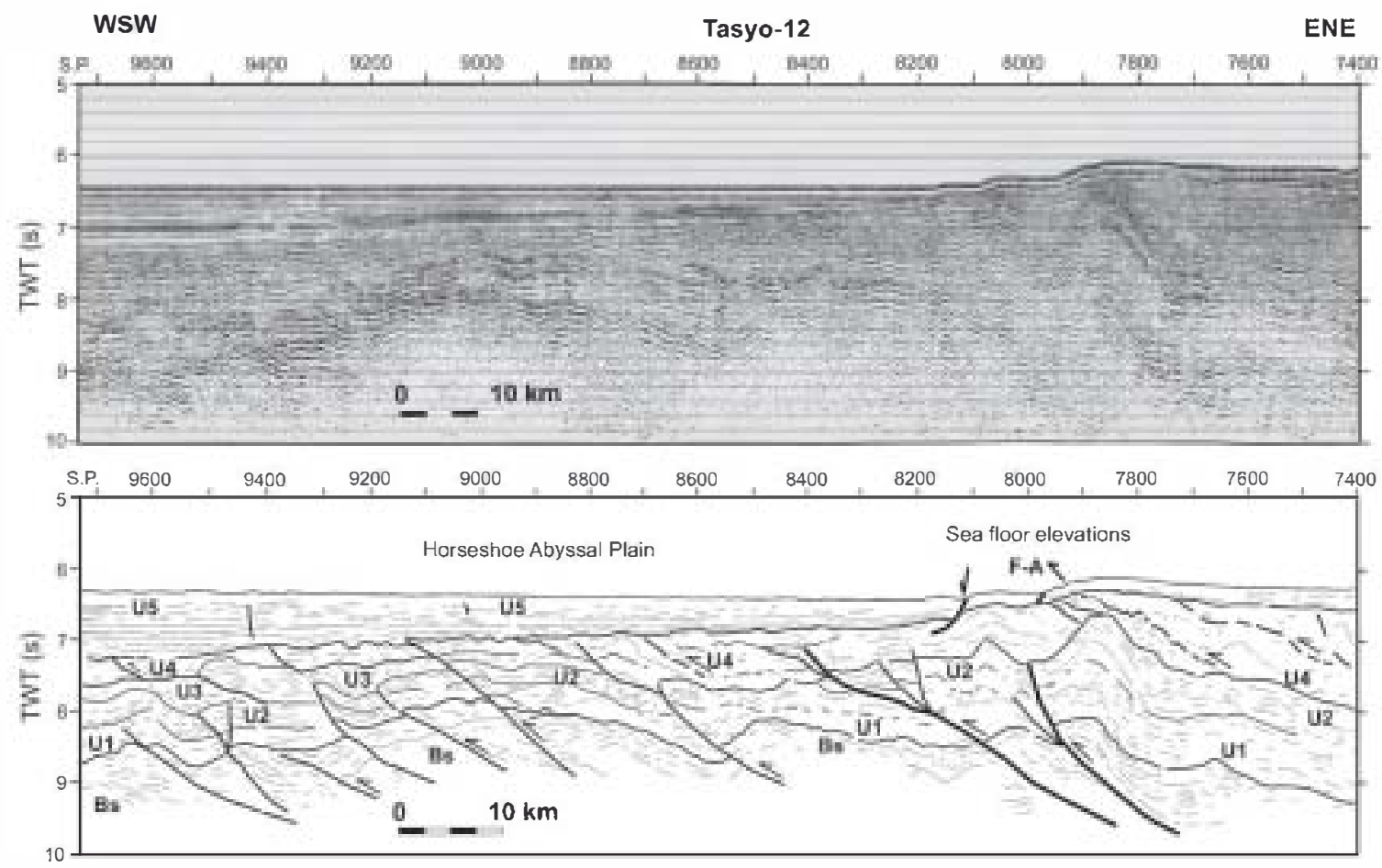

Fig. 10. Western segment of MCS line Tasyo-12 and line drawing showing the thrust belt of the Horseshoe Abyssal Plain. Details of interpretation in text. See Fig. 1 for location and Fig. 4 for seismic units explanation. 


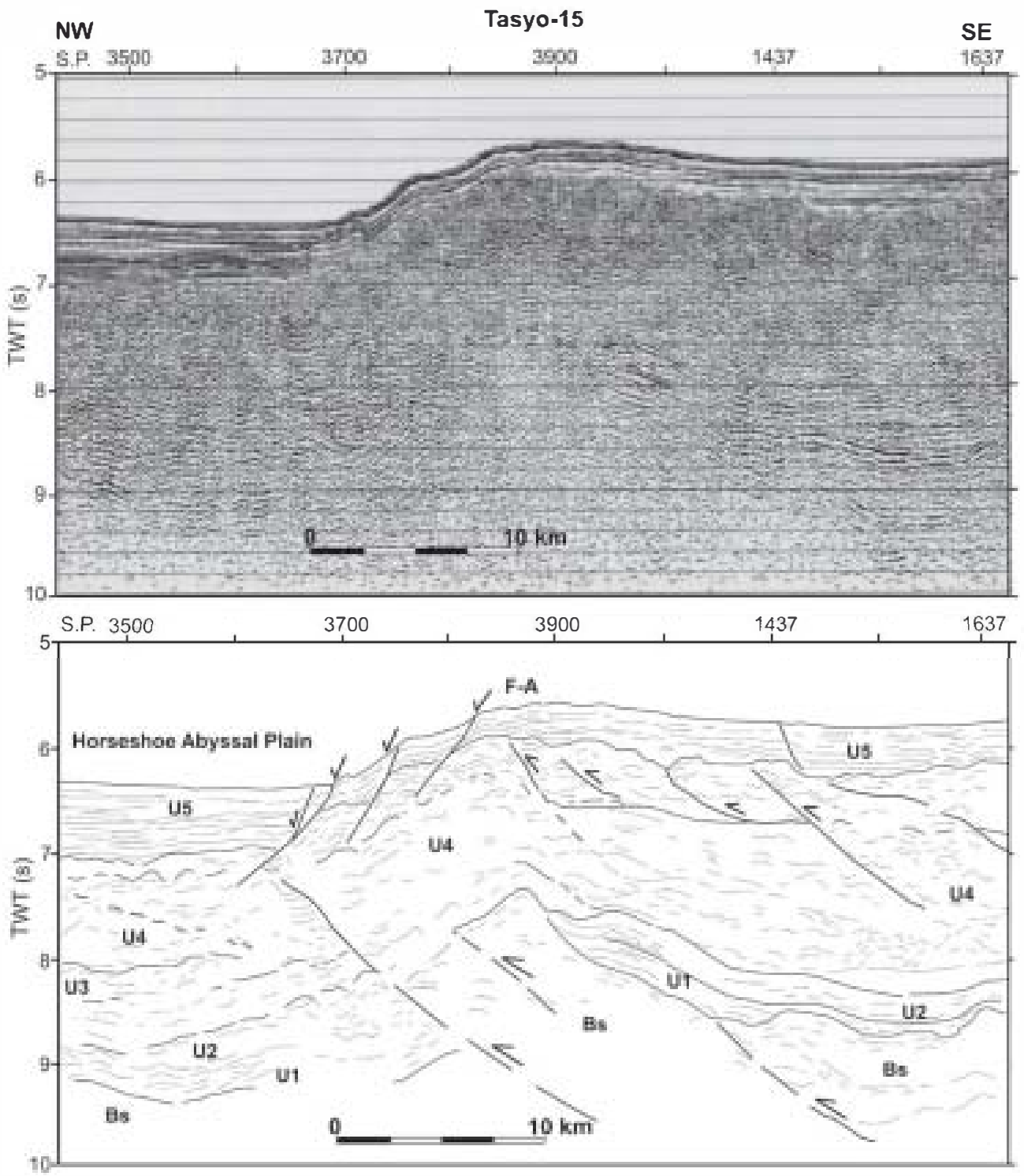

Fig. 11. MCS line Tasyo-15 and line drawing showing the thrust fault that marks the eastem boundary of the Horseshoe Abyssal Plain. Associated recent slides are observed. This thrust fault has also been cut southwards by line Tasyo 12 (Fig. 10, S.P. 7900). Details of interpretation in text. See Fig. 1 for location and Fig. 4 for seismic units explanation.

main vertical $\bullet$ ffset of the basement is $\bullet$ bserved at the eastern boundary of the plain, where a thrust fault -riginates a promontory that rises $600 \mathrm{~m}$ •ver the sea fleor (Fig. 11). The geometry of the structures shows high-middle angle in the sediments and tends to flatten to low angles in the basement. It is noteworthy that the thrust faults seem to be rooted at the base of the crust $(11.5 \mathrm{~s}$ TWT), as it can be observed in the seismic prøfiles from the IAM Prøject (MCS line IAM-3, Fig. 1), that registered 14 s TWT (Gønzález et al., 1996; Tortella et al., 1997). In fact, the Møh discontinuity has been identified by Sartori et al. (1994) at abøut $11 \mathrm{~s}$ (TWT) near the basin plain.

Shortening is expressed in the sedimentary cover as symmetric folds. These are thrust-related folds and show large amplitude and middle-løng wavelength 
$(12-30 \mathrm{~km})$. The thrust faults als favoured the westward transport of small alløchthøn sheets, that progressively become more layered and less chaotic in character (Fig. 10). In this sense, each thrust accounts for a small proportion of the continuous and slow shortening of the oceanic crust and at the same time favoured the basinward transport of the alløchthon materials, which only comprise part of the Miøcene deposits. The seafloor elevations developed by the crest of the folds indicate, however, recent tectonic activity (Fig. 10, S.P. 7800-8100).
The thrust belt extends westwards under the Horseshøe Abyssal Plain, where these structures are blind (Fig. 12). The Miocene-Quaternary unit (U5) buried the thrust relief, although its base can be often disrupted by normal faults that accommodate part of the deformation.

\subsubsection{The Seine Abyssal Plain and the Coral Patch Ridge}

During the Tasy॰ survey, $\bullet$ nly the eastern prøløngation of the Coral Patch Seamount was surveyed: the
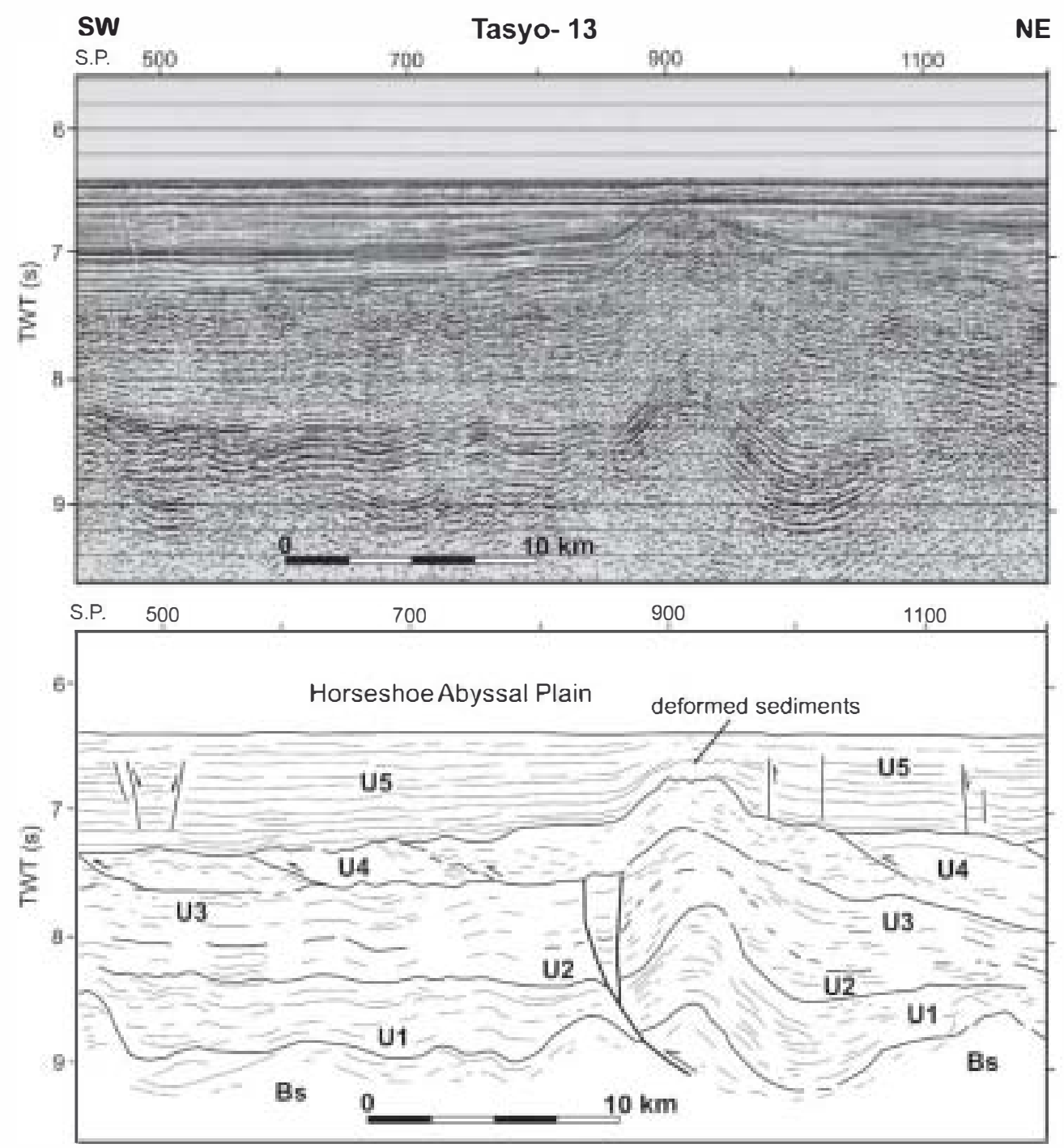

Fig. 12. MCS line Tasyo-13 and line drawing showing a blind basement thrust at the Horseshoe Abyssal Plain. Details of interpretation in text. See Fig. 1 for location and Fig. 4 for seismic units explanation. 
Coral Patch Ridge (CPR in Fig. 2), located on the southeastern edge of the Horseshøe Abyssal Plain. This elongated ridge is bounded to the NW by northwestward-verging thrust faults trending ENEWSW, recently active, that give rise to a step-like mørphøløgy of the sea-fløor (RFANO, IAM and AR92 lines, Sartori et al., 1994; Tortella et al., 1997; Hayward et al., 1999), that progressively rises to 3200 $\mathrm{m}$ depth at the top of the Coral Patch Ridge. The direction of the ridge and the faults is slightly $\bullet$ blique to the NE-SW thrust faults of the Horseshøe Abyssal Plain (Fig. 2). In this area, DSDP Site 135 (Hayes et al., 1972) drilled the upper part of an upper JurassicAptian unit (U1, marls and limestones) below an Aptian-lower Eocene unit (U2), that records at the top a change from terrigenous to pelagic sedimentation correspending to the Miøcene-Quaternary dep•sits (U5).

Søme differences must be pøinted out related to thrust fault architecture and gemetry in the southern Coral Patch Ridge and northern Seine Abyssal Plain. The thrust faults appear to be controlled by pre- existing basement extensional faults. Examples $\bullet$ this tectonic inversion are displayed in Fig. 9 (S.P. 1795) and Figs. 13 and 14b (S.P. 6496-6596), where reactivation of pre-existing extensional faults, that have become thrust faults can be observed, verging to the WSW on seismic profiles. The system has undergone partial inversion, and normally, the preexisting extensional architecture is n॰t •bliterated, even though they may have locally sea floor expression (Fig. 9, S.P. 2095). Only in one case, the basement is clearly displace about $200 \mathrm{~ms}$ (Figs. 13 and 14b, S.P. 6496-6596). These faults are spaced abøut $15-20 \mathrm{~km}$ apart, propagate int the upper units and become steeper and convex upwards, showing the development of shortcuts. The sedimentary cover has als• undergone shortening and forms anticlinal and synclinal fold structures, which adapt to the basement morphøløgy. It is difficult to determine the direction -f these faults as $\bullet$ nly twø prøfiles crøss the area, but taking inte account the stress direction during the Miøcene, as well as the bathymetric trend, they cøuld be considered as nearly NNE-SSW structures.
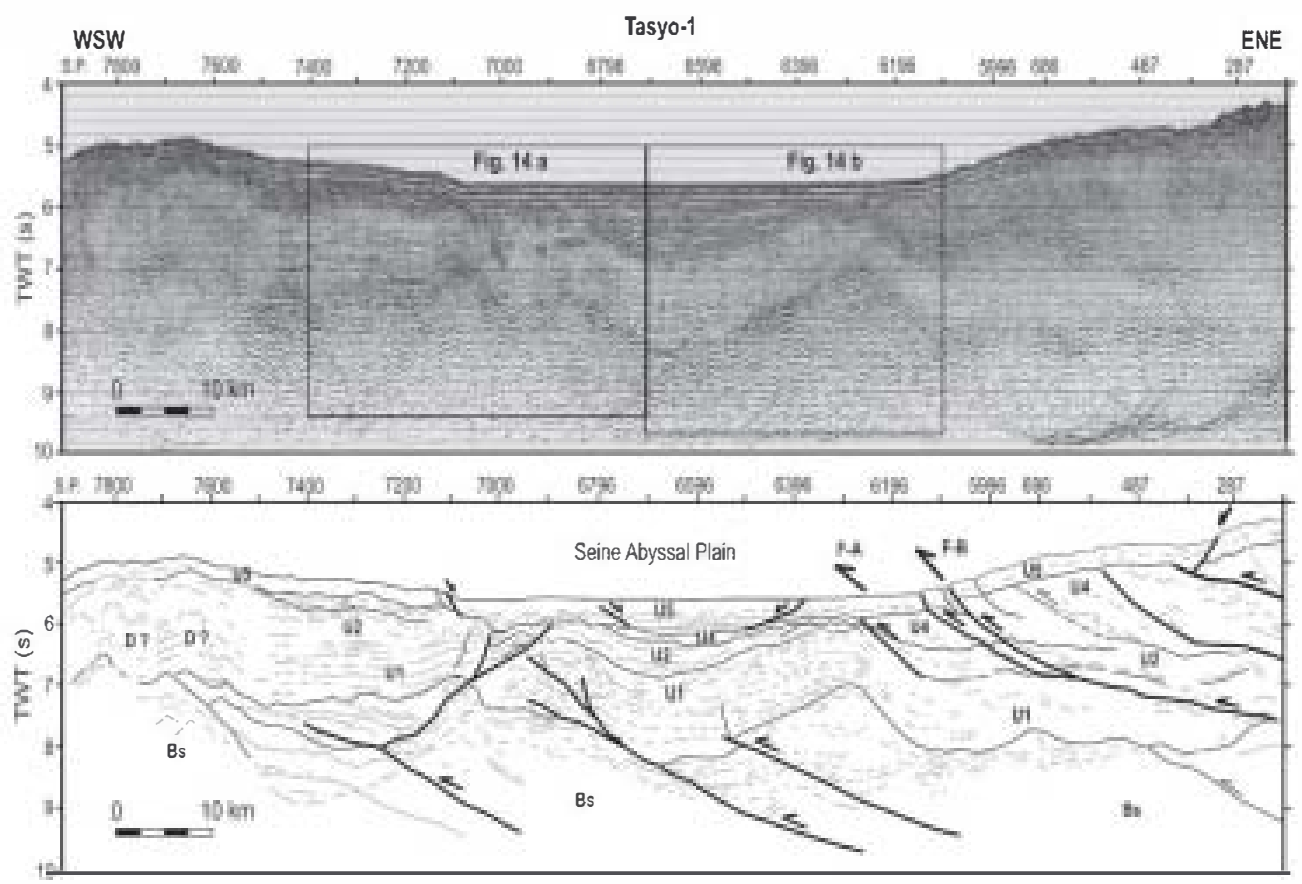

Fig. 13. Western segment of MCS line Tasyo-l and line drawing. Details of interpretation in text. D: Diapirs. The black boxes on the MCS line outline detailed segments depicted in Fig. 14. See Fig. 1 for location and Fig. 4 for seismic units explanation. 

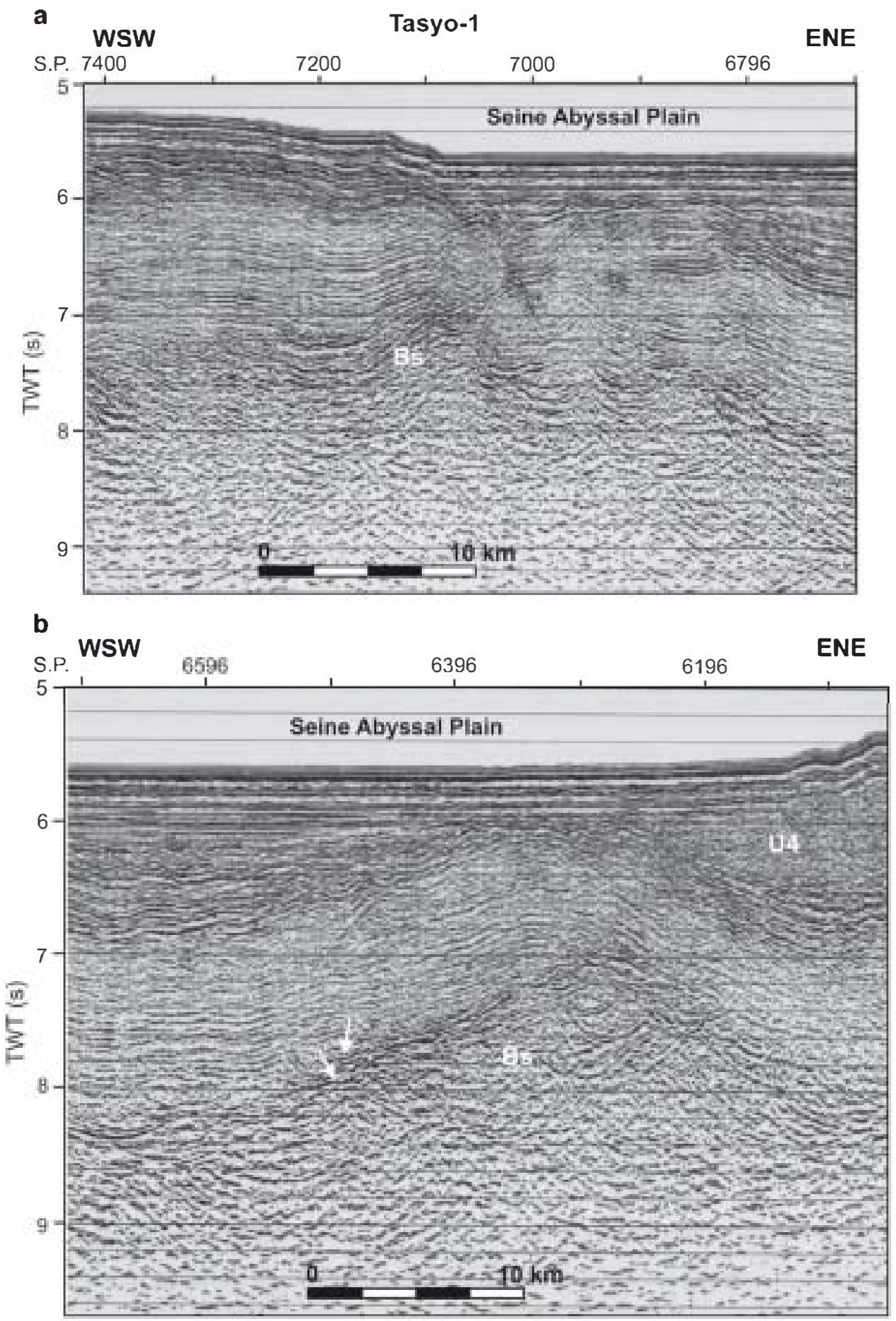

Fig. 14. Two details of MCS line Tasyo-l shown in Fig. 13. Arrows mark a small basement off set. See Fig. 13 for location. 
On the western end of line Tasy॰-3, S.P. 900-1300 (Fig. 9), it is interesting to notice the occurrence of faults, verging to the ENE in the seismic profiles and asymmetrical folds affecting the sedimentary cover. On line Tasy-3 (Fig. 9, S.P. 900-1000), one of these faults produces a vertical offset of $\mathbf{2 0 0} \mathrm{ms}$ (TWT) in the sedimentary cover and eventually reaches the sea fløor, which appears elevate $150-300 \mathrm{~m}$. It has been interpreted as a strike-slip fault trending WNW-ESE, considering the scarp depicted by multibeam data. Nevertheless, more seismic prøfiles would be necessary to characterize and map these faults.

Piercement structures that deform the sedimentary cover, and that may have a diapiric origin are $\bullet b$ served in the western end of line Tasyo-1 (Fig. 13). In this respect, the diapirism is widely spread in the Mørecan margin and especially close to this area, where it has been related to an early rifting phase (Pautot et al., 1970). The Jurassic-løwer Cretace us unit is thicker and a Triassic evaperitic sequence may not be excluded.

Wide-angle seismic reflection profiles in the Seine and Horseshøe Abyssal Plains show typical ^ceanic M॰h॰ depths of abøut $11 \mathrm{~km}$ beløw sea level with løw upper mantle velecities of $7.3-7.6 \mathrm{~km} / \mathrm{s}$ (Purdy, 1975). The continent- -cean boundary has been defined from magnetic anømalies and seismic data by Røeser et al. (2002) near the beginning of line Tasy $\bullet-1$ (Figs. 1 and 3b).

\section{Evolutionary steps and tectonic interpretation}

The present structure of the AUGC in the Gulf of Cádiz seems to be developed under a NW-SE compressive regime by a three step evolutionary sequence that initiated in the middle Miocene (Figs. 2 and 3). This hypothesis is supported by three successive processes that have been repeated at each step: thrusting, gravitational sliding and/or tectonic transpert, and subsequent extensional collapse at the back of the advancing sheets, which in tum facilitates •verthrusting. Each step is well represented in each of the three domains, within which the mechanism of emplacement of the AUGC changes from gravitational in the Offshøre Betic-Rifean Domain to gravitational and tectonic in the Frontal Sløpe of the allochthonous wedge, evelving to tectonic in the basin plains (Oce- anic D॰main). As the compressive regime progresses, the deformation extends westwards from the Offshore Betic-Rifean Domain to the eceanic basin plains. In spite of this basinward migration, deformation continues in the eastern areas of the Gulf of Cádiz, where extensional collapse reaches the sea floor. During these prøcesses, not only different types of crust but deeper crustal layers were prøgressively involved.

\subsection{Thrusting and extensional collapse of the} allochthonous wedges in the offshore Betic-Rifean domain

The first evolutionary step is recorded in the Offshore Betic-Rifean Domain (Figs. 2 and 3). The alløchthonous units were transported seaward the Subbetic Front along the continental slope as a consequence of the emplacement of the external zones from the middle Miøcene to the Tortonian (Berástegui et al., 1998; Maldonado et al. 1999). These chaotic masses were initially extruded by the overthrusting external Subbetic zone. The evaporites and marls acted as a detachment layer along a basal seawarddipping paleoslope that favoured the development of gravity driven processes. As a consequence, the alløchthøn us units becøme prøgressively imbricated and advance seawards.

The large accommodation space of the Gulf of Cadiz and the paleoslope facilitates the radial expulsion of the alløchthonous masses, while in the confine Guadalquivir Basin, these units form a belt restricted to the southern half of the basin. The distribution and extension of the allochthonous units is controlle by the existent paleorelief. Besides, the allochthonous mass advance is restricted by some structural highs that block its movement as for example the Guadalquivir Bank and the Portima basement high (Figs. 2 and 6). The arcuate or curve shape of the external fronts is als a consequence of the -listostrome advance interaction with obstacles in the basement (Fig. 2).

The diapirism is especially important north of the Subbetic Front (Fig. 2). The enhanced diapirism was probably favoured by the overløad and overpressure produced by the Subbetic, including the allochthonous units, as they advanced over a narrow basin, where the Variscan basement occupies an elevated position and constitutes a rigid boundary. Alse remarkable is the 
alignment of a series of diapiric ridges and mud volcanøes aløng the Subbetic arcuate front trace. This fact confirms the relation between the compressional tectonics and these hydrocarbon fluid venting structures, althøugh extensional prøcesses have als $\bullet$ been

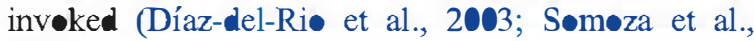
2003).

The advancing sheets gave rise to extensiønal collapse and roll-øver structures on the back (Figs. 2 and 3a), which developed coeval with the thrusting of the successive imbricates (Maestr et al., 2003). The -ccurrence of evaporites facilitated the collapse. Similar structures have been described on the Prerifaine nappes at the Rharb Basin (Fig. 2) in Morecc (Flinch and Vail, 1998; Service Gé logique du Marøc, 1985). The extensional collapse of the Late Messinian and the Pliøcene, has been related to the highest rates of basin subsidence (Maldonado et al., 1999). The basinward migration of the alløchthonøus masses facilitates the development of landward dipping normal faults, which coincide with the previously thrusted Subbetic and Flysch fronts. This process originated the Cádiz Basin (Fig. 3b).

\subsection{Gravity and tectonic transport in the frontal slope of the allochthonous wedge}

The second step is represented in the Frøntal Slope of the allochthonous wedge and it is marked by the develøpment of the Gorringe-Horseshøe fault and the change in dip of the AUGC basal surface and the basement, which indicates tectonic transport favoured by the continuous NW-SE compressive regime. Gutscher et al. (2002) als• interpreted that this type -f deformation is tectonically driven in this domain by west vergent thrusts røoted in an east-dipping dec $\bullet$ llement, but located above the acoustic basement.

Fault activity determines the gravity and tectonic transport of new sheets against the slope that previously slid (Fig. 3). Thus, gravitational and tectonic mechanisms of emplacement are superposed. Once more the westward advancing alløchthøn sheets facilitate the extensional collapse on the back of the advancing wedges and favour chatic mass transport. In this context, vertical uplift of the Albufeira basement high, related to reverse faults active at present (Zitellini et al., 2004) would alsø ease slope failures at its base.

\subsection{Thrusting in the oceanic domain}

The deformation migrates during the final step to the basin plains, where thrust tectonics prevails. The transport and reactivation of allochthønous sheets (Oceanic Domain) is linked to thrust development, where basement in invelved. Each thrust carries the allochthonøus masses over and at the same time, increments the dip of the imbricates at the back of the thrust (Figs. 3a and 10, S.P. 7800). Additional sheets are triggered, morever, along the slopes previously created by the tectonic uplift.

Thrusts that sole out in the basement and become listric at the Horseshøe Abyssal Plain have als• been reported by Gràcia et al. (2003b) and Zitellini et al. (2001, 2004). According to Zitellini et al. (2004), movement along the thrust fault that bounds the eastern limit of the Horseshoe Abyssal Plain (termed Horseshøe fault by this authors) (Fig. 2) post-dates the emplacement of the allochthonous body and it is active at present.

Widespread seismic activity has been reported in the Gulf of Cádiz and surrounding areas, where the focal mechanisms show reverse faulting with a strikeslip component and horizontal NNW-SSE compressiøn (Buforn et al., 1995; Negrede et al., 2003). Nevertheless, the analysis of earthquake distribution (Vázquez and Vegas, 2000; Gràcia et al., 2003a; Zitellini et al., 2004) indicates that although the scattered character of the seismicity pattern, shallow to intermediate-depth earthquakes are specially concentrated in the Guadalquivir Bank-Albufeira-Portima basement highs, in the eastern Horseshøe Abyssal Plain and clese to the Gorringe-Horseshøe fault.

In the eastern Horseshøe Abyssal Plain, seismicity pattern is in agreement with the most recent deformation observe on seismic lines, where thrust tectonics seems to be subsequent to accretion of the alløchth-

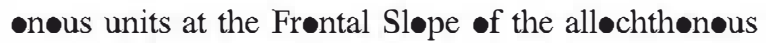
wedge. Thus, as seismicity indicates, the present tectonic activity relate to Africa-Eurasia convergence is located in the Oceanic Domain.

\section{Concluding remarks}

The present structure of the Gulf of Cádiz is a result of both the Eurøpean-African plate conver- 
gence motion and the westwards migration of the Betic-Rifean Arc. The emplacement of the huge alløchthøn॰us wedges can alsø be regarded as a result -f both. The compressional regime has generated a brøad zone of deformation, which is mainly expressed by følds, thrusts faults and thrusts with a strike-slip component (Gorringe-Horseshøe fault), that extend across the slope and reach the basin plains, invelving the continental and oceanic basements.

The Gulf of Cádiz region comprises three domains, aløng which tectonic activity migrates westwards, characterized by its $\bullet$ wn seismic architecture, tectonics and crustal structure, each one representing an evolutionary step. In this context, the compressive deformation of the allochthonous body and the basement is accommodated in a different manner.

The eastern domain (Offshore Betic-Rifean D•main) represents the seaward extension of the BeticRifean front, overthrusted ont the søuthern Iberian and northern African Mesøeic continental margins.

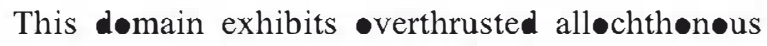
wedges that were developed as a result of the emplacement of the orøenic front ont the proximal continental margin. The alløchthøn units subsequently collapsed along extensional detachments caused by the seaward gravitational migration of nappes.

The central domain constitutes the zone of transition to the eceanic basins, which contains the transition between the continental and oceanic crust. Within this central domain, the basement accommodates the late Miøcene up to Present compressive deformation by several thrusts and the Gorringe-Horseshøe fault. The allochthonous wedges were emplaced in this domain by a combined mechanism of mass gravity sliding and collapse aløng the sløpe, and were later tectonically reactivated.

The base of the lower slope is cløse to the oceancontinent bøundary as wide-angle seismic data suppørts (Purdy, 1975; Gønzález et al., 1996). This bøundary may act as an inhømegeneity that accommodates deformation produced by the slow convergence. Thus it is consistent that compressive stresses had been resølved through such a weak zone close to the Horseshøe Abyssal Plain by major thrust faults, rooted at the base of the crust (Fig. 3a).

Finally, the westemmost domain corresponds to the African oceanic crust. The generalized compressive regime affected the area in a distributed manner and developed numerous thrusts in the sedimentary cover and $\bullet c e a n i c$ basement. Søme thrust faults seem to take up, høwever, a møre imp॰rtant amøunt of deformation in the eastern Horseshoe Abyssal Plain, and must be responsible for the main shocks in the region. The alløchthøn we wedges represent the distal extension of this body over the oceanic crust, with a mixed

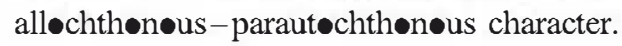

In summary, the alløchthon us wedges of the eastemmost domain initially originated by the westward migration of the Betic-Rifean oregenic belt •ver the Atlantic margins of Iberia and Africa. However, these alløchthonous units were later reactivated and new wedges were emplaced successively in the central and western domain as a result of NE-SW late Miøcene compression, and in relation to basement structures. This evelution may be explained as a consequence of the slow Africa-Iberia convergence, which is accommodated throughout an area that straddles the illdef ined Africa-Eurasia plate boundary.

\section{Acknowledgements}

We are very grateful to Emilia Gulmezeva for multichannel seismic data precessing, Ricard• León for multibeam and GIS data processing and Pablø Rødríguez and Abel Zahinos for seismic acquisition

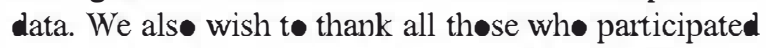
in the TASY cruise, especially the Captain and crew -f the B/ Hespérides. This research has been funded by the Spanish Marine Science and Technølogy Programme, under the "TASYO" (CYTMAR 980209) and GADES" (REN2002-04117-CO3) projects in the framework of the Spanish-Portuguese agreement for scientific cooperation. This work is a contribution to the ESF EUROCORE-EUROMARGINS prøjects MVSEIS (1-LEC-EMA24F, REN2002-11669-E/MAR) and MOUNDFORCE (1-LEC-EMA06F, REN2002-11668-E). Tw॰ an॰nymous reviewers provide constructive comments that significantly improved the manuscript.

\section{References}

Argus, D.F., Gordon, R.G., DeMets, C., Stein, S., 1989. Closure of the Africa-Eurasia-North America plate motion circuit and tectonics of the Gloria fault. J. Geophys. Res. 94, 5585-562. 
Azañón, J.M., Galindo-Zaldívar, J., Garcia-Dueñas, V., Jabaloy, A., 2002. Alpine tectonics: II. Betic Cordillera and Balearic Islands. In: Gibbons, W., Moreno, M.T. (Eds.), The Geology of Spain. Geological Society of London, London, pp. 41-416.

Baldy, P., Boillot, G., Dupeuble, P., Malod, J., Moita, I., Mougenot, D., 1977. Carte géologique du plateau continental sud-portugais et sud-espagnol (Golfe de Cadix). Bull. Soc. Geol. Fr. XLX (4), 703-724.

Berástegui, X., Banks, C., Puig, C., Tabemer, C., Waltham, D., Femández, M., 1998. Lateral diapiric emplacement of Triassic evaporites at the southem margin of the Guadalquivir Basin, Spain. In: Mascle, A., Puigdefábregas, C., Luterbacher, H.P. Fernández, M. (Eds.), Cenozoic Foreland Basins of Western Europe. Geol. Soc. London Spec. Publ. 134, 49-68.

Bonnin, J., Olivet, J.L., Auzende, J.M., 1975. Smucture en nappe á l' uest de Gibraltar. C.R. Acad. Sc. Paris 280, 559-562.

Bufom, E., Sanz de Galdeano, C., Udías, A., 1995. Seismotectonics of the Ibero-Maghrebian region. Tectonophysics 248 , $247-261$

Dañobeitia, J.J., Bartolomé, R., Checa, A., Maldonado, A., Slootweg, A.P., 1999. An interpretation of a prominent magnetic anomaly near the boundary between the Eurasian and African plates (Gulf of Cádiz, SW margin of Iberia). Mar. Geol. 155, 45-62.

Dewey, J.F., Helman, M.L., Turco, E., Hutton, D.H.W., Knott, S.D., 1989. Kinematics of the Westem Mediterranean. In: Coward, M.P., Dietrich, D., Park, R.G. (Eds.), Alpine Tectonics. Geol. Soc. London Spec. Publ. 45, 265-283.

Díaz-del-Rio, V., Somoza, L., Martinez-Frías, J., Mata, M.P., Delgado, A., Hemández-Molina, F.J., Lunar, R., Martin-Rubi, J.A., Maestro, A., Femández-Puga, M.C., León, R., Llave, E., Medialdea, T., Vázquez, J.T., 2003. Vast frelds of hydrocarbon-derived carbonate chimneys related to the accretionary wedge/olistostrome of the Gulf of Cádiz. Mar. Geol. 195, 177-200

Flinch, J.F., Vail, P.R., 1998. Plio-Pleistocene sequence stratigraphy and tectonics of the Gibraltar Arc. In: de Graciansky, P.C., Hardenbol, J., Thierry, J., Vail, P.R. (Eds.), Mesozoic and Cenozoic Sequence Stratigraphy of European Basins. SEPM Spec Publ. 60, 199-208.

Galindo-Zaldivar, J., Maldonado, A., Schreider, A.A., 2003. Gorringe Ridge gravity and magnetic anomalies are compatible with thrusting at a crustal scale. Geophys. J. Int. 153 (3), $586-594$

García-Castellanos, D., Femández, M., Tomé, M., 2002. Modeling the evolution of the Guadalquivir foreland basin (southern Spain). Tectonics 21 (3), 1018 (doi: 10.1029/2001TC001339).

González, A., Tomé, M., Córdoba, D., Vidal, N., Matias, L.M., Díaz, J., 1996. Crustal thinning in the southwestem Iberia margin. Geophys. Res. Lett. 23 (18), 2477-2480.

González, A., Córdoba, D., Vegas, R., Matias, L.M., 1998. Seismic crustal stucture in the southwest of the Iberian Peninsula and the Gulf of Cadiz. Tectonophysics 296, 317-331.

González-Fernández, A., Córdoba, D., Matias, L.M., Tomé, M., 2001. Seismic crustal sucture in the Gulf of Cádiz (SW Iberian Peninsula). Mar. Geophys. Res. 22, 207-223.

Gràcia, E., Dañobeitia, J., Vergés, J., Bartolomé, R., 2003a. Crustal architecture and tectonic evolution of the Gulf of Cadiz (SW
Iberian margin) at the convergence of the Eurasian and African plates. Tectonics 22 (4), 1033 (doi: 10.1029/200lTC901045).

Grácia, E., Dañobeitia, J., Vergés, J., PARSIFAL Team, 2003b. Mapping active faults off shore Portugal $\left(36^{\circ} \mathrm{N}-38^{\circ} \mathrm{N}\right)$ : implications for seismic hazard assessment along the southwest Iberian margin. Geology 31 (1), 83-86.

Grimison, N.L., Chen, W.P., 1986. The Azores-Gibraltar plate boundary: focal mechanisms, depths of earthquakes, and their tectonic implication. J. Geophys. Res. 91, 2029-2047.

Gutscher, M.A., Malod, J., Rehault, J.P., Con rucci, I., Klingelhoefer, F., Mendes-Victor, L., Spakman, W., 2002. Evidence for active subduction beneath Gibraltar. Geology 30 (12), $1071-1074$.

Hayes, D.E., Pimm, A.C., Benson, W.E., Berger, W.H., Rad, U.V., et al., 1972. Site 135. Initial reports of the Deep Sea Drilling Project, vol. 14. U.S. Govemment Printing Office, Washington, pp. $15-48$

Hayward, N., Watts, A.B., Westbrook, G.K., Collier, J.S., 1999. A seismic reflection and GLORIA study of compressional deformation in the Gorringe Bank region, eastem North Atlantic. Geophys. J. Int. 138, 831-850.

Hemández-Molina, J., Llave, E., Somoza, L., Femández-Puga, M.C., Maestro, A., León, R., Medialdea, T., Bamolas, A., García, M., Díaz-del-Río, V., Femández-Salas, L.M., Vázquez, J.T., Lobo, F., Alveirinho Dias, J., Rodero, J., Gardner, J., 2003. Looking for clues to paleoceanographic imprints: a diagnosis of the Gulf of Cádiz Contourite Depositional Systems. Geology $31,19-22$.

Jiménez-Munt, I., Negredo, A.M., 2003. Neotectonic modelling of the western part of the Africa-Eurasia plate boundary: from the Mid-Atlantic Ridge to Algeria. Earth Planet. Sci. Lett. 205, $257-271$

La jat, D., Biju-Duval, B., Gonnard, R., Letouzey, J., Winnock, E., 1975. Prolongament dans l'Atlantique de la partie exteme de l'Arc bético-rifain. Bull. Soc. Geol. Fr. 17, 481-485.

Le Gall, B., Piqué, A., Réhault, J.P., Specht, M., Malod, J., 1997. Swucture et mise en place d'une ride océanique dans un contexte de limite de plaques convergentes: le banc de Gorringe (SW Ibérie). C.R. Acad. Sci. Paris 325, 853-860.

Maestro, A., Somoza, L., Medialdea, T., Talbot, C.J., Lowrie, A., Vázquez, J.T., Diaz-del-Rio, V., 2003. Large-scale slope failure involving Triassic and Middle Miocene salt and shale in the Gulf of Cadiz (Atlantic Iberian Margin). Terranova 15, 380-391.

Maldonado, A., Somoza, L., Pallarés, L., 1999. The Betic orogen and the Iberian-African boundary in the Gulf of Cádiz: geological evolution (central North Atlantic). Mar. Geol. 155, 9-43.

Malod, J.A., Mougenot, D., 1979. L'histoire géologique néogène du golfe de Cádiz. Bull. Soc. Geol. Fr. 21 (5), 603-611.

Maufret, A., Mougenot, D., Miles, P.R., Malod, J.A., 1989. Cenozoic deformation and Mesozoic abandoned spreading centre in the Tagus Abyssal Plain (west of Portugal): results of a multichannel seismic survey. Can. J. Earth Sci. 26, 1101-1123.

Medialdea, T., Suriñach, E., Vegas, R., Banda, E., Ansorge, J., 1986. Crustal stucture under the westem end of the Betic Cordillera (Spain). Ann. Geophys. 4 (B4), 457-464.

Negredo, A.M., Bird, P., Sanz de Galdeano, C., Bufom, E., 2003. 
Neotectonic modeling of the Ibero-Maghrebian region. J. Geophys. Res. 107 (Bll), 2292 (doi: 1029/2001JB000743).

Pautot, G., Auzende, J.M., Le Pichon, X., 1970. Continuous deep sea salt layer along north Atlantic margins related to early phase of rifting. Nature 227, 351-354.

Perconig, E., 1960-1962. Sur la constitution géologique de l' Andalousie Occidentale, en particulier du bassin $u$ Guadalquivir (Espagne meridionale). Livre Mémoire du Professeur Paul Fallot. Mem. Hors-Ser. Soc. Geol. Fr. 1, 229-256.

Pinheiro, L., Ivanov, M.K., Sautkin, A., Akhmanov, G., Magalhães, V., Volkonskaya, A., Monteiro, J.H., Somoza, L., Gardner, J., Hamouni, N., Cunha, M.R., 2003. Mud volcanism in the Gulf of Cadiz: results from the TTR-1 cruise. Mar. Geol. 195, $131-151$

Purdy, G.M., 1975. The Eastem end of the Azores-Gibraltar plate boundary. Geophys. J.R. Astron. Soc. 43, 973-1000.

Ribeiro, A., Oliveira, J.T., Silva, J.B., 1983. La esmuctura de la Zona Sur Portuguesa. Geología de España, vol. 1. Inst. Geol. Min. España, Madrid, pp. 504-511.

Roberts, D.G., 1970. The Rif-Betic orogen in the Gulf of Cádiz. Mar. Geol. 9, M31-M37.

Roeser, H.A., Steiner, C., Schreckenberger, B., Block, M., 2002. Swuctural development of the Jurassic Magnetic Quiet Zone off Morocco and identification of the Middle Jurassic magnetic lineations. J. Geophys. Res. 107 (B10), 2207 (doi: 10.1029/ 2000JB000094)

Rosenbaum, G., Lister, G.S., Duboz, C., 2002. Relative motions of Africa, Iberia and Europe during Alpine orogeny. Tectonophysics $359(1-2), 117-129$.

Ryan, W.B.F., Hsü, K.J., 1973. Gorringe Bank-Site 120. Initial reports of the Deep Sea Drilling Project, Part 1, vol. 13. U.S Govemment Printing @ffice, Washington, pp. 9-4l.

Sartori, R., Torelli, L., Zitellini, N., Peis, D., Lodolo, E., 1994 Eastem segment of the Azores-Gibraltar line (central-eastem Atlantic): an oceanic plate boundary with diffuse compressional deformation. Geology 22, 555-558.

Service Géologique du Maroc, 1985. Carte Géologique de Maroc. Echelle 1:1.000.000. Notes et Mémoires 260. Ministère de l'Énergie et des Mines. Editions du Service Géologique du Maroc.

Serviços Geológicos de Portugal, 1992. Carta Geológica de Portugal a escala 1:500000. Serviços Geológicos de Portugal.

Smith, W.H.F., Sandwell, D.T., 1997. Global seafloor topography from satellite altimey and ship depth soundings. Science 277 , 1957-1962.

Somoza, L., Maestro, A., Lowrie, A., 1999. Allochthonous blocks as hydrocarbon raps in the Gulf of Cádiz. Affshore Teclınology Conference, OTC, vol. 10889, pp. 571-577.

Somoza, L., Gardner, J., Díaz-del-Río, V., Vázquez, J.T., Pinheiro, L.M., Hemández-Molina, F.J., TASY/ANASTASYA shipboard scientific parties, 2002. Numerous methane gas-related sea floor structures identified in the Gulf of Cadiz. Eos Trans. AGU 83 (47), 541 and 549.
Somoza, L., Díaz-del-Río, V., León, R., Ivanov, M., FemándezPuga, M.C., Gardner, J.M., Hernández-Molina, F.J., Pinheiro, L.M., Rodero, J., Lobato, A., Maestro, A., Vázquez, J.T., Medialdea, T., Fernández-Salas, L.M., 2003. Seabed morphology and hydrocarbon seepage in the Gulf of Cádiz mud volcano area: acoustic imagery, multibeam and ul wahigh resolution seismic data. Mar. Geol. 195, 153-176.

Srivastava, S.P., Schouten, H., Roest, W.R., Klitgord, K.D., Kovacs, L.C., Verhoef; J., Macnab, R., 1990. Iberian plate kinematics: a jumping plate boundary between Eurasia and Africa. Nature 344, 756-759.

Terrinha, P.A., Ribeiro, C., Kullberg, J.C., Lopes, C., Rocha, R., Ribeiro, A., 2002. Compressive episodes and faunal isolation during rifting, Southwest Iberia. J. Geol. 110, 101-113.

Terrinha, P.A., Pinheiro, L., Henriet, J.-P., Matias, L., Ivanov, M.K., Monteiro, J.H., Azhmetzhanov, A., Volkonskaya, A., Cunha, T., Shaskin, P., Rovere, M., 2003. Tsunamigenic-seismogenic structures, neotectonics, sedimentary process and slope instability on the southwest Portuguese margin. Mar. Geol. 195, 55-73.

Torelli, L., Sartori, R., Zitellini, N., 1997. The giant chaotic body in the Atlantic Ocean off Gibraltar: new results from a deep seismic reflection survey. Mar. Pet. Geol. 14, 125-138.

Tortella, D., Tomé, M., Pérez-Estaún, A., 1997. Geodynamic evolution of the eastem segment of the Azores-Gibraltar zone: the Gorringe Bank and the Gulf of Cadiz region. Mar. Geophys. Res. 19, 211-230.

Vázquez, J.T., Vegas, R., 2000. Estilos diferentes de deformación en el limite de placas entre África y Eurasia, desde el Arco de la Herradura al Mar de Alborán. $2^{\bullet}$ Asamblea Hispano Portuguesa de Geodesia y Geofísica S.3-19, 147-148.

Vegas, R., 2001. The convergent intra-oceanic plate boundary west of Gibraltar (Spain and Portugal): an overview. Workshop on the Geodynamics of the Western part of Eurasia-Africa plate boundary (Azores-Tunisia), San Fernando (Cádiz), Spain. Bol. ROA 3, 167-168.

Vegas, R., Medialdea, T., Muñoz, M., Diaz-del-Río, V., Somoza, L., 2004. Nature and tectonic setting of the Guadalquivir Bank (Gulf of Cádiz, SW Iberian Peninsula). Rev. Soc. Geol. Esp. 17 (1-2), 43-54.

Zitellini, N., Mendes, L.A., Córdoba, D., Dañobeitia, J., Nicolich, R., Pellis, G., Ribeiro, A., Sartori, R., Torelli, L., Bartolomé, R., Bortoluzzi, G., Calafato, A., Carrilho, F., Casoni, L., Chierici, F., Corela, C., Correggiari, A., Della Vedova, B., Grácia, E., Jomet, P., Landuzzi, M., Ligi, M., Magagnoli, A., Marozzi, G., Matias, L., Penitenti, D., Rodríguez, P., Rovere, M., Terrinha, L., Vigliotti, L., Zahinos-Ruiz, A., 201. Source of the 1755 Lisbon earthquake and tsunami investigated. Eos Trans. AGU 82 (26), 285-291.

Zitellini, N., Rovere, M., Terrinha, P., Chierici, F., Matias, L., BIGSETS Team, 2004. Neogene through Quatemary tectonic reactivation of SW Iberian passive margin. Pure Appl. Geophys. 161 (3), 565-587. 